\title{
CONFLITOS NA CONSTRUÇÃO DE IDENTIDADES DE GÊNERO: A PEDAGOGIA SEXUAL VIABILIZADA POR PRÁTICAS DISCURSIVAS, MIDIÁTICAS E PUBLICITÁRIAS
}

\author{
CONFLICT IN THE CONSTRUCTION OF GENDER IDENTITY: \\ THE SEXUAL PEDAGOGY MADE POSSIBLE BY DISCURSIVE \\ PRACTICES, MEDIA AND ADVERTISING
}

FRANCISCO MACIEL SILVEIRA FILHO

\begin{abstract}
Resumo
Na certeza de que as identidades de gênero são metamorfoses, frutos de processos em constante mutação nos quais os elementos sociais, culturais, políticos e sexuais estão intrinsecamente ligados de forma inexorável e determinante, o presente artigo tem por objetivo investigar o quanto as práticas discursivas viabilizadas por suas diferentes vertentes tem contribuído de forma crucial para que associemos sexo e gênero de forma intrínseca, como se o amálgama que os une fosse fruto da natureza e não de forças usadas a serviço de uma sociedade machista, misógina e homofóbica. Para tanto, a pedagogia sexual, valendo-se de técnicas propaladas pela mídia, pela publicidade, e pela literatura serão visitadas e discutidas com o intuito de aprofundar as discussões pretendidas.
\end{abstract}

Palavras-chave: mídia, publicidade, pedagogia sexual, identidades de gênero.

\section{Abstract}

The certainty that gender identities are metamorphoses, fruits changing processes in which the social, cultural, political and sexual are inextricably linked inexorably and decisive, this article aims to investigate how the discursive practices made possible by its different aspects has contributed crucially to associate sex and gender intrinsically, as if the glue that binds them was the result of forces of nature and not used in the service of a sexist society, misogynist and homophobic. For this purpose, sexual pedagogy, drawing on techniques propagated by the media, advertising, and literature will be visited and discussed in order to deepen the discussions required.

Keywords: media, advertising, sexual pedagogy, gender identities.

Refletindo sobre o modo atávico através do qual os discursos foram construídos na Modernidade, e observando a forma como a prática discursiva foi disseminada e utilizada, dentre outros objetivos, para o controle da

12 Professor das Universidades Presbiteriana Mackenzie e Salesiana. Psicólogo clínico, Mestre em relações de gênero pela USP e doutorando em Psicologia Social pela PUCSP. e-mail: macielsf@ vol.com.br 
nossa sexualidade, Guacira Lopes Louro (1997, p.41) elucida: "Os discursos constroem determinados significados e, assim, legitimam específicas identidades de gênero".

Segundo a autora, é, no meio social, sempre político, que as diferenças que categorizam e hierarquizam os sujeitos são produzidas.

Os meios através dos quais se incutem nos meninos e meninas, via variadas formas de discurso, o que se espera deles em função do seu sexo morfológico são dos mais impensados e poderosos, de modo que a sua utilização irrefletida e disseminada contribui para a manutenção das representações relativas às relações de gênero, do modo como discutimos e contestamos na atualidade.

Poderíamos começar pelo fato de ocultarmos, na construção das frases que envolvem sujeitos masculinos e femininos, o elemento feminino, massificando o conjunto pelo seu elemento dominante - no caso, o masculino, sinônimo de invisibilidade, sobre o qual não se faz necessária a contestação. O mesmo se dá pelo uso de aumentativos, quando em referência a meninos, e diminutivos, quando em referência a meninas. Prosseguiríamos com a utilização desigual de adjetivos ligados à força, determinação e coragem, quando falando de homens, e de adjetivos ligados à ternura, afeição e meiguice, quando tratamos de mulheres, de tal modo que essa repetição faz soar natural e esperado o fato de mulheres serem dóceis e boazinhas, enquanto homens devem ser valentes, fortes e poderosos, tornando todos aqueles que não se enquadrem nesse panorama seres inadequados ao seu sexo morfológico. Utilizar tal discurso, na maioria das vezes cômodo e viciado, permite uma perpetuação da instituída superioridade masculina sobre a mulher.

Corroborando o que apontamos acima, Weeks (2001, p. 41) nos diz que "a linguagem da sexualidade parece ser avassaladoramente masculina".

Reforçamos a importância discursiva na construção das relações de gênero mencionando o fato de termos um Deus criado e concebido enquanto entidade masculina, o que, por si só, acaba dando aos homens uma posição central no universo. Do lugar ocupado no centro do universo para a posição de centro de referência norteador das relações de gênero, o caminho percorrido pelos seres do sexo masculino foi curto. Caminho que, não esqueçamos, foi também pavimentado pelas mulheres.

$\mathrm{Na}$ construção de um processo que diferencie homens e mulheres, embasando tratamentos díspares em função da anatomia, citamos o fato de que, se as meninas são constantemente encaminhadas para a repetição de um modelo de feminilidade que reflita um ideal calcado nas figuras da mãe e da esposa ideais, fato que lhes limita e restringe as possibilidades asseguradas às suas subjetividades, no que tange à educação masculina, aos meninos são impostos controles pedagógicos relativos aos seus comportamentos e fantasias, que os fazem crescer achando que todos os demais são da forma como lhes dizem que deveriam ser. Quando não conseguem se comportar de maneira adequada para suprir as expectativas do enges- 
samento patriarcal e machista, sentem-se problemáticos e diferentes. Como não são estimulados, como as meninas, a compartilharem seus mundos internos e seus conseqüentes anseios, tendem a reforçar e engrandecer o modelo vigente.

O problema quanto à expressão dos sentimentos seria um dos pontos a se destacar como muito importante no processo de criação de meninos e meninas, e é calcado na prática através da qual aos meninos é ensinado silenciar quanto a seus problemas e dificuldades, desenvolvendo-se um mecanismo de afastamento das situações que envolvam vergonha e medo, sinais aparentes de uma fragilidade e de uma fraqueza que aprenderam não ser dignas e nem constituintes da masculinidade hegemônica.

Enquanto o medo e a insegurança são evitados a qualquer preço, cedo se ensina aos meninos que, através do sucesso e dos ganhos permitidos pelas conquistas sexuais e pelo trabalho, sua identidade masculina, nos moldes do que é esperado convencionalmente, poderá ser alcançada a contento.

Desse panorama, constrói-se a idéia de que os homens só se sentem homens quando realizam atividades externas a si mesmos, que não exijam intimidade, interiorização e afetividade.

Entretanto, os meninos, em sua maioria, passam a ser criados para assumir comportamentos intimistas que favoreçam a discrição quanto aos seus problemas e dificuldades, na mesma medida em que são estimulados a serem contundentes quanto aos seus méritos e vitórias amorosas ou profissionais, mesmo que sejam tais narrativas frutos de suas prodigiosas imaginações ou desejos.

Ouçamos o que diz Nolasco acerca do assunto:

A educação de um menino, tal como concebida por nossa cultura, desenvolve-se valorizando mais o esfacelamento das características emotivas da dinâmica subjetiva da criança do que propriamente um modelo de homem que transcenda as fronteiras de seu sexo e do uso que deve fazer do mesmo. Ao longo de sua vida, um menino vai aprendendo a sufocar e a não revelar o que sente. Com isto, sutilmente vai abandonando a si mesmo, e deste abandono nasce a ilusão de que a incorporação do estereótipo do macho lhe concederá, quando adulto, o resgate do paraíso perdido na infância (NOLASCO, 1993, P.47).

Segundo nos alerta o autor, os meninos, desde muito cedo, têm medos muito próprios como os de perder os atributos construídos social e historicamente como sendo próprios do universo masculino, fato que os tornaria imperfeitos aos olhos da sociedade machista da qual são constituintes e constituídos. O mesmo pode ser constatado no universo feminino das meninas em seu percurso de socialização sexual. O medo constante, existente para ambos os sexos, de uma possível não-adequação aos modelos preestabelecidos de sexualidade acaba por não permitir aos seres humanos serem ativos e/ou passivos, viris e/ou submissos, masculinos e femininos, inde- 
pendentemente do seu sexo morfológico. A necessidade de se escamotear essa possibilidade amedrontadora acaba por não permitir às pessoas um questionamento que viesse a colocar em cheque todo um sistema patriarcal sob o qual se sustentam as civilizações modernas.

De forma complementar a toda uma pedagogia sexual, podemos mencionar a utilização pelos adultos de frases norteadoras do comportamento e da conduta sexual, tais como "Não se comporte como uma menina, afinal isso não é coisa de homem" ou "Você não quer crescer para se tornar um homem forte e decidido como seu pai?" ou "Menina não faz isso, menina não fala palavrão". Constatamos que todas essas frases são importantes ferramentas sociais para incutir nas crianças o medo de que, ao não se comportarem como se espera de um membro do seu sexo morfológico, possam deixar de pertencer a esse sexo, como se isso fosse possível a despeito das evidências anatômicas em contrário.

Essa ameaça acaba sendo usada para impor uma série de detaIhes relativos à rotina educacional e à expressão das emoções masculinas e femininas. Fatores como a vaidade pessoal e os interesses em roupas ou cosméticos passam a ser usados para limitar e definir as potencialidades de ambos os sexos. Felizmente, tais fronteiras começam a sofrer uma flexibilização recente e bastante tardia, passando a permitir avanços saudáveis aos universos masculino e feminino.

Amparados na constatação acima, e cientes de que nossos estudos se concentram na modernidade, julgamos interessante mencionar a idéia de Taylor (1997, p.216-218), que atribui à criação das roupas pelos homens pré-históricos, há cerca de 1,6 milhões de anos, o surgimento da idéia de gênero. Segundo o autor, desde o surgimento das vestimentas havia roupas masculinas e roupas femininas, fato que desenvolveu na humanidade uma nova dimensão em relação à consciência sexual.

Avançando em nossas discussões acerca das práticas discursivas que tanto contribuíram para a configuração do panorama sexual que agora esboçamos, podemos mencionar a literatura e o jornalismo no século XIX atuando no sentido de reafirmar os ideais de masculinidade e feminilidade construídos como dominantes através de folhetins e romances concebidos enquanto veículos difusores de informações para as massas. Corroborando nosso entendimento, Oliveira (1993, p.114) nos diz que "a literatura foi domínio reservado do mundo cultural masculino".

Muitos desses veículos passaram a ser utilizados como forma de manter as mulheres enquadradas e aprisionadas nos moldes que as enraizaram durante tanto tempo. A descaracterização de um gênero que fosse concebido estaticamente como sendo só masculino ou só feminino, e a de uma linguagem formulada enquanto neutra na construção de seus significados, foram duas batalhas que se iniciaram no século XIX e se perpetuaram ao longo do século XX, corporificando-se através das lutas sociais empreendidas pelas ditas minorias preocupadas em acabar com a hegemonia branca, masculina, heterossexual e monogâmica, entronizada como sendo o grande parâmetro no qual todos os demais grupos periféricos deveriam se esforçar para se enquadrar, em um trabalho de mutilação das diferenças e das 
peculiaridades que constituem o humano (CAMPOS, 2001, p.7-16).

No empenho para a construção de um cenário machista e patriarcal, a literatura em muito ajudou na cristalização de papéis demarcados e engessados em sua possibilidade de vir a ser, que tanto caracterizou a transitoriedade das identidades. Ao instaurar como sujeito absoluto dos romances o modelo de homem heterossexual e patriarcalista, relegou para as bordas sociais todos os demais grupos que não se enquadrassem nessa categorização e que passaram a exercer o duplo papel do distanciamento e do fascínio provocado pelo diferente e não compreendido. Do medo do diferente e da possibilidade de sucumbir ao novo que se apresenta como tentador, surge a necessidade de controlar para evitar o imprevisto, o não planejado e o desnorteador. As bordas e as fronteiras são criadas como forma de garantir a preservação desse lugar espúrio de direitos e reconhecimentos ao qual foram relegadas as minorias consideradas transgressoras. Transgressão que se avoluma pelo perigo que apresenta quando ameaça deixar de ser o diverso, para se equiparar ao modelo instituído como adequado, numa situação que acabaria por minar o poder exercido até então pelas categorias nele instituídas. Segundo Oliveira,

A criação artística e literária, enquanto elã de comunicação com o público - gesto, palavra ou imagem endereçados a todos, anônimos, desconhecidos -, enquanto voz voltada para o mundo, não poderia, por isso, ser voz feminina. A não ser como transgressão da regra fundadora que, separando o Masculino do Feminino, atribui a uns e outros estilos, modos de expressão que lhes são próprios e não apropriáveis pelo outro sexo (1993, p. 114).

Embora não nos possamos esquecer de que já nesse momento houvesse nomes favoráveis à igualdade social feminina, muitos foram os pilares da literatura e do jornalismo a atuar de forma ambígua, ora lutando pela igualdade das mulheres, ora tomando atitudes que só fizeram corroborar o esquematismo do seu papel social e sexual. De qualquer modo, em certo momento do percurso jornalístico, a imprensa deixou de se orientar para os homens enquanto leitores e passou a considerar as mulheres enquanto seu público leitor, reconhecendo-as como um grupo de sujeitos de direito, prerrogativas às quais elas mesmas não estavam acostumadas e que representaram um grande avanço (CAMPOS, 2001, p. 25).

A edificação dos papéis femininos em romances voltados para as muIheres teve sempre como foco a reiteração dos ideais masculinos defendidos e esperados, fosse a monogamia da esposa e mãe dedicada ao lar, fosse o caráter fogoso da mulher mestiça e exótica. Tendo por público as mulheres e os adolescentes, o romance romântico atuou como meio de persuadir ideológica e psicologicamente o público feminino no trabalho constante de reafirmação dos modelos tradicionais de gênero. Por meio da literatura romântica e folhetinesca, buscou-se congelar, nas mentes despreparadas para os questionamentos dos gêneros, as representações identitárias que o poder patriarcal pretendia conservar e manipular. Mais uma vez, materiali- 
za-se a certeza de que, alienadas de suas potencialidades, peculiaridades e direitos, as mulheres se tornaram objeto fácil de manobrar por mãos mais espertas e ardilosas.

Mesmo as poucas mulheres das mais altas classes a se aventurarem no universo literário do século XIX fizeram-no quase que travestindo um modo de pensar e de se expressar masculino, como afirma Oliveira:

O século XIX deixou como herança uma estranha mistura: uma literatura próxima da literatura masculina da época, porém atravessada por um amargor muito feminino, marca inconfundível das autoras divididas, tentando escrever como homens sem deixar o lugar da mulher que se sente excluída (1993, p. 118).

Reforçando as práticas discursivas utilizadas para viabilizar o controle da sexualidade, discutido por Foucault a partir do século XVII e a pedagogia da diferenciação sexual, realizada pela literatura e pelo jornalismo a partir do século XIX, vemos emergir o século XX com seus mecanismos de controle e manipulação das diferenças.

Do mesmo modo que a educação de meninos e meninas é de fundamental importância para justificar o modo como se configuram as relações de gênero, o mesmo se pode dizer das práticas midiáticas. Também considerada um mecanismo determinante na produção e na reiteração de identidades, a mídia opera no sentido de apresentar modelos hegemônicos de feminilidade e de masculinidade que acabam por incutir nos sujeitos a noção exata daquilo que deles se espera em virtude de serem homens ou mulheres. Se no século XIX a literatura feminina exercia o papel de demarcar espaços e limites para os indivíduos em virtude de seu sexo, no século XX e XXI boa parte dessa responsabilidade pode ser atribuída aos discursos veiculados pela publicidade.

Podemos considerar a publicidade como um dos mecanismos educativos mais presentes nas instâncias sócio-culturais da atualidade. Valendo-se de artefatos propalados como educativos, acaba por se inserir na área cultural via televisão, cinema, revistas, livros ou histórias em quadrinhos. Funciona como mecanismos que educam e geram conhecimentos, contribuindo, assim, no processo de produção de identidades. Tomemos como exemplo as revistas femininas que passam a ditar para suas leitoras as condutas, hábitos, costumes, roupas, exercícios e artefatos de consumo, tudo isso com o propósito claro de regular e orientar o caminho que se espera dessas mulheres.

Como exemplifica Ruth Sabat em Gênero e sexualidade para consumo, artigo que discute a importância da mídia na construção da sexualidade moderna e que compõe a obra Corpo, Gênero e Sexualidade - Um debate contemporâneo na educação (2003):

A publicidade impressa trabalha basicamente com imagens. As imagens produzem uma pedagogia, uma forma de ensinar as coisas do mundo, produzem conceitos ou pré-conceitos sobre diversos aspectos sociais, produzem 
formas de pensar e agir, de estar no mundo e de se relacionar com ele. A construção de imagens que valorizam determinado tipo de comportamento, de estilo de vida ou de pessoa, é uma forma de regulação social que reproduz padrões mais comumente aceitos em uma sociedade (SABAT, 2003, p. 150).

Ainda, segundo a autora,

Os signos que importam são aqueles relacionados ao gênero e à sexualidade. São constantes as apresentações de mulheres como mães/donas-de-casa e de homens como provedores do lar. Do mesmo modo, o modelo hegemônico de família composto de pai, mãe, filho e filha, além de um animal de estimação, pode ser observado em propagandas de margarinas, de planos de saúde, de carros de passeio e tantos outros produtos (SABAT, 2003, p. 152).

Assim, nos discursos publicitários temos representações que estão sempre relacionadas com o conhecimento presente na sociedade e que normalmente são conflitantes com os fomentos educacionais, na medida em que o que é proposto educativamente é contradito por aquilo que a publicidade pretende incutir em seu público alvo. Infelizmente, cria-se uma dicotomia desnorteante entre o que é proposto e aquilo que é efetivamente colocado em prática.

É possível perceber por meio de quais formas são socialmente construídos tipos de corpos, modos de viver, comportamentos e valores apresentados nas imagens, considerando o potencial crítico que as representações de gênero e de sexualidade na publicidade comportam. Percebemos, então, como os sujeitos podem ser constituídos a partir de um modelo predominante, correspondente ao sistema político, social e cultural no qual estão inseridos, conforme declara Sabat:

Cercados como estamos por imagens, o acesso às revistas e, conseqüentemente, à publicidade por elas veiculada, é mais uma etapa no processo de consumo, em que os sujeitos consomem não só mercadorias como também valores que estabelecem como deve ser o corpo, como devemos nos vestir, quais comportamentos valorizar. Isso tudo não somente através das marcas de gênero, como também das de raça/etnia, classe e geração (SABAT, 2003, p. 153).

Como local de produção de significados, a mídia também é um lugar em que são representados códigos culturais e signos nos quais os significados são trocados. Cada elemento que compõe um anúncio publicitário é um signo que nos permite entender a imagem de acordo com os códigos culturais que carregamos.

Segundo a compreensão de Hall acerca do assunto, "a capacidade que possuímos de dar sentido às coisas está amparada em 'mapas de signi- 
ficados' que compartilhamos culturalmente e por meio dos quais representações são construídas" (apud SABAT, 2003, p. 156).

Pensar de forma crítica relativamente a todas as informações que nos são passadas diariamente implica, segundo Sabat, um esforço para o qual muitos não estão preparados de pronto:

Uma leitura crítica, ao contrário, requer um processo de estranhamento, conceito tão caro à Antropologia; tal leitura invoca um olhar ativo, através do qual as imagens e as representações que elas carregam podem ser contestadas e questionadas em função dos significados então presentes (SABAT, 2003, p. 155).

A publicidade oferece elementos suficientes para refletirmos acerca da sociedade e a respeito de nós mesmos de acordo com modelos dominantes. Sem dúvida, a função da propaganda é vender mercadorias divulgando suas qualidades. Entretanto, tais qualidades precisam, de alguma forma, fazer-nos sentido; daí a necessidade de utilizar referentes, ou seja, símbolos, "figuras" que tenham relação com o cotidiano e o histórico compartilhado em determinada sociedade por um ideal coletivo. Entretanto, não basta somente produzir novas imagens ou signos, sendo necessário que seja produzida toda uma teia de significantes interligados para que possamos nos identificar com o que vemos. É importante que uma imagem, ao mesmo tempo que nos permita novos processos de significação, também possibilite que os signos já com seus respectivos referentes em nossa vida cotidiana tenham espaço de expressão dos sentidos.

Pelas imagens publicitárias podemos observar como as relações de gênero estão sendo vistas por determinada sociedade. Ao utilizar mulheres para divulgar marcas de sabão em pó ou homens para divulgar marcas de cigarros mais fortes, o discurso publicitário está se apropriando de significados que estão circulando nas relações sociais. Simultaneamente, reafirmamse e naturalizam-se estas mesmas representações. Conforme propõe Chauí,

Na propaganda, os estereótipos dos papéis sexuais- sociais reconhecidos, respeitados ou admirados, são reforçados: os produtos são anunciados de modo a manter e legitimar o que é "próprio da mulher", "próprio do homem", "próprio de adulto", "próprio de criança", "próprio de adolescente", "próprio de velho (evidentemente, nada é anunciado diretamente como "próprio" dos "pervertidos"). Não apenas mulheres anunciam produtos para mulheres, homens para homens, crianças para crianças, adolescentes para adolescentes, velhos para velhos (pois cada qual teria o seu mundo próprio), mas ainda há trocas de ofertantes: mulheres e homens anunciam produtos através da sedução, erotizando o objeto pela medicação de quem o oferece; crianças são utilizadas para garantir a veracidade do produto, pois 
a criança é inocente e sincera e seus atributos se transferem para os objetos; velhos garantem a utilidade ou eficácia do produtos porque os velhos são experientes e esse atributo é transferido para os objetos; e, anuncio perfeito, o recurso aos especialistas (médicos, dentistas, engenheiros, professores, psicólogos, executivos, etc.), porque são conhecedores da verdade, garantem a autenticidade e boa qualidade dos produtos (Chauí, 1984, p. 160).

Na disposição de vender determinada idéia ou produto, é produzida uma pedagogia que narra o sujeito como independente e livre para fazer escolhas, ao mesmo tempo em que se relaciona com os mecanismos de (auto) controle e de (auto-)regulação, normatizando as relações sociais e materializando-as através das imagens.

É importante não esquecer que o discurso publicitário não é autônomo, não tem vida própria. Quando a publicidade fala, somos também nós que falamos. O discurso publicitário constitui-se de práticas cotidianas exercidas na sociedade. Está imerso em tais práticas e é nelas que encontra objetos para construir sua própria materialidade.

Nada garante que a mensagem publicitária comporte uma leitura única. Os signos podem ser apreendidos de formas diferentes e é essa possibilidade que nos permite fazer uma leitura crítica do modo como as imagens publicitárias atuam no processo de formação de identidades atreladas às representações de gênero.

Não podemos deixar de lembrar que interpretar é produzir sentidos, da mesma forma que todo o ato de interpretar é realizado por alguém que já dispõe, desde o início dessa interpretação, de um arcabouço de materiais disponíveis para tanto. Segundo Foucault (2004, p.99), tudo o que existe é fruto de uma interpretação, já que cada símbolo existente é a interpretação de outros símbolos que o originaram e não do produto que se oferece para interpretação.

Como esclarece Ciampa,

Com isso, estabelece-se uma intricada rede de representações que permeia todas as relações, onde cada identidade reflete outra identidade, desaparecendo qualquer possibilidade de se estabelecer um fundamento originário para cada uma delas (CIAMPA, 1987, p. 171).

Do mesmo modo que a linguagem funciona como produtora de analogias em função do sexo morfológico, que para nós é tido como um sinal que materializa corpos e distingue indivíduos, também o faz em função de aspectos interligados ao gênero, como cor, classe, posição social, entre outros. Em nossa visão, faz-se necessário compreender que a diferenciação sexual nunca se dá somente tendo como base a biologia e a anatomia dos indivíduos, incluindo-se no mesmo rol as práticas discursivas que dessas diferenciações se valem para amparar e justificar argumentos muitas vezes 
usados como incontestes.

Sem deixar de navegar por campos culturais e sociais que tanto contribuem para a construção das diferenciações entre os gêneros, não podemos esquecer de mencionar aqueles cujos trabalhos atestam a existência de diferenças, a quais, para além do discurso social, constroem-se pelas estruturas biológicas e genéticas dos indivíduos, reforçando as trincheiras utilizadas pelas correntes biologizantes.

Quando encontramos pesquisadores e estudiosos que se amparam em aspectos puramente biológicos para explicar as diferenças entre homens e mulheres, devemos focar não as distinções e sua importância, mas sim, o modo como essas constatações "científicas" foram usadas para reforçar um discurso que ajudou a disseminar a idéia de que homens e mulheres são diferentes em virtude primordialmente do seu sexo morfológico, esvaziando em grande medida a relevância sócio-histórica do processo constitutivo desses discursos e dessas representações. As diferenças apontadas têm relevância, uma vez que homens e mulheres são diferentes. Mas o modo como essas diferenças são usadas é que nos permite entender todo um processo sócio -histórico extremamente relevante no cenário da sexualidade humana.

Este deve ser nosso ângulo de percepção quando nos deparamos com informações atestando que, enquanto os homens possuem predomínio de habilidades espaciais em decorrência de a parte frontal do hemisfério direito do cérebro ser mais desenvolvida que no sexo feminino, as mulheres possuem predomínio das habilidades sensoriais em decorrência de um corpo caloso mais grosso, responsável por processar várias informações ao mesmo tempo, decifrando sinais visuais e verbais com muito mais eficiência. Desse modo, as mulheres conseguem integrar melhor as informações vindas das duas partes do cérebro, enquanto os homens, pelo predomínio da quantidade de testosterona, hormônio masculino por excelência, conseguem maior sucesso em questões que envolvam a necessidade de localização.

Segundo estudiosos que se dedicam a essas comparações, o duplo cromossomo $\mathrm{X}$ das mulheres garante-lhes a vantagem de distinguir melhor as cores, em virtude do maior número e variedade de células fotorreceptoras, bem como a de expressar-se com mais fluência, uma vez que têm no cérebro duas regiões (uma em cada hemisfério) específicas para a fala.

Como já apontado, mais importante do que nos atermos às informações fornecidas por esses autores, o que acreditamos ser relevante é a mensagem que o seu discurso abarca.

Acreditam aqueles que se baseiam nessas informações para construir um discurso que diferencie as pessoas em função de suas características orgânicas, que estariam nos processos embriológico e biológico as origens e as causas que justificariam as questões de gênero. Ressaltamos que essa explicação nos parece bastante simplista, pois alienaria da construção sócio-histórica toda a responsabilidade, nas representações de gênero, que passariam a ser concebidas a partir de uma biologia diferencial dos sexos, conforme enfatiza Chauí: 
Nossa sociedade conseguiu transformar as diferenças anatômicas entre homens e mulheres em papéis e em tipos sociais e sexuais, criando uma verdadeira zoologiasociologia sexual. Reprime, assim, a ambigüidade constitutiva do desejo e da sexualidade fazendo da diferença e da multiplicidade sexuais um tormento um crime, uma doença e um castigo (1984, p. 33).

Como uma teia composta por múltiplas tramas, a junção dos efeitos produzidos pela biologia, pela pedagogia, pela publicidade e pela aculturação, associados a todas as modificações produzidas no seio das famílias burguesas nas quais a repressão e o controle da sexualidade foram talhados, acabou por resultar no surgimento de um centro, materializado na figura do homem de classe média, branco, ocidental, heterossexual, que vem usufruindo, ao longo dos tempos e de um modo praticamente inabalável, uma posição privilegiada em torno da qual todas as demais categorias gravitam.

Portanto, muito mais do que um sujeito, o que passa a ser questionado, é todo um modo de ser social, econômico, político, cultural e sexual de homens e mulheres.

Para a configuração de uma posição, construída como central ou não, o referencial sempre será relativo àquilo que temos como atributo e que não é compartilhado por aqueles a quem queremos isolar. Por meio desse processo de exclusão é que as sociedades modernas delimitaram as normas e seus contornos, determinando aqueles indivíduos que estão e os que não estão em adequação aos padrões culturais eleitos para fundar tais preceitos. Em virtude de tais ideais regulatórios, passaram a existir as concepções de centro e as de margens/bordas.

Na posição central estão os homens heterossexuais, brancos e urbanos, que não mais precisam ser nomeados, cabendo a todos os demais indivíduos as posições periféricas que se constituem a partir do centro. Os sujeitos, dotados das prerrogativas e dos privilégios atribuídos adquirem o direito de representar e expressar a si e a todos os outros, elegendo sua estética, seus pontos de vista e seus desejos como se fossem, para toda uma universalidade de pessoas, os "corretos e esperados". Representam, dessa forma, por meio da subordinação ou da negação, todos aqueles não-enquadrados sob o manto "da visibilidade".

Neste sentido nossas idéias encontram acolhida em Almeida (2000, p. 149-155), para quem a masculinidade hegemônica corresponde a uma variedade bastante particular de masculinidade que acaba por subordinar drasticamente outras de suas tantas variedades. As masculinidades que acabam sendo não-hegemônicas subsistem reprimidas e auto-reprimidas por um conjunto de símbolos e significados que materializam o centro e soterram toda e qualquer possibilidade de uma concepção dinâmica de masculinidade.

Desse modo, quando usamos o masculino para nos referir a pessoas de ambos os sexos ou falamos em pessoas de cor para nos referimos aos não brancos, passamos a reforçar a concepção construída de que ser homem e 
ser branco são marcas tão invisíveis e determinantes que deixam mesmo de ser identificadas enquanto gênero e cor. Neste singular instante, reduzem-se os indivíduos a um dos muitos elementos componentes da sua subjetividade, optando-se, para essa massificação, por aquilo que lhes é mais ou menos aparente, dominante, ou social e culturalmente aceito. O mesmo pode ser dito de todas as categorias criadas correspondendo a modelos inatingíveis que só acentuam o sofrimento dos não adequados àquilo veiculado e proposto paulatinamente.

As "novas" identidades culturais que começam a se originar da não -adequação ao centro de referência nos obrigam a reconhecer que a cultura, longe de ser homogênea e monolítica, é, de fato, complexa, múltipla, desarmônica e descontínua. Essas novas identidades, denominadas de "excêntricas", passaram não só a ganhar importância nestes tempos pós-modernos, como, mais do que isso, passaram a se constituir como novo alvo das atenções. Como nos declara Oliveira (1993, p. 72), "só através dessa recusa assumida pelos desviantes, de agir conforme o código dominante, é que pode ocorrer a transformação das normas e dos comportamentos vigentes".

Na medida em que somos todos "ex-cêntricos" e "marginais", pois ocupamos posições que estão sempre muito distantes dos ideais utópicos propostos pelas práticas discursivas hegemônicas, nosso movimento, enquanto grupo social responsável por refletir sobre mudanças necessárias e prementes, não pode se limitar a inverter as posições que são ocupadas por aqueles categorizados como dominadores e por aqueles concebidos como dominados. Em vez disso, supomos aproveitar este deslocamento para demonstrar o caráter construído do centro - e também o das margens. A universalidade e a estabilidade do lugar central resultam de uma história que tem sido constantemente reiterada e de um movimento de reforço que a faz parecer tão verdadeira quanto inatingível. Por outro lado, ceder à facilidade de reverter o jogo praticado, transformando as margens em centro, constituir-se-á no mesmo processo político e excludente até então vivenciado. Mais adequado e proveitoso talvez seja o questionamento que nos permita vislumbrar e assimilar o caráter construído, não só o do centro como também o das margens, indo inclusive na direção das interfaces nas quais ambos se encontram, complementam e reforçam.

Não podemos perder de vista o fato de "ex-cêntrico" ser tudo aquilo que está fora do centro, constituindo-se como extravagante e esquisito. Já a posição central é confeccionada como a posição não-problemática. Ao conceito de centro se vinculam, freqüentemente, noções de universalidade, de unidade e de estabilidade. Os sujeitos e as práticas culturais que não ocupam este lugar recebem as marcas da particularidade, da diversidade e da instabilidade. Acreditamos, entretanto, que somente mediante a existência de seres e práticas qualificadas como diferentes é que se permitirá a abertura de flancos através dos quais as discussões aqui entabuladas aconteçam e evoluam. E como as diferenças sempre se constroem no âmbito das relações, tais questionamentos ampliam as discussões para as esferas das relações de poder e dominação, cujas interfaces estão intimamente ligadas 
à forma como as relações de gênero se configuram.

As contínuas afirmações e reafirmações desse lugar privilegiado nos fazem acreditar em sua universalidade e permanência, ajudando-nos a esquecer seu caráter construído e levando-nos a conceder-lhes a aparência de algo "natural". Não somente o conceito de centro, mas também o de "ex-cêntrico", são ficções construídas ao longo dos tempos, via apropriação e divulgação do discurso hegemônico, de modo a nos garantir a ilusória idéia de uma ordem e unidade a orientar nossas ações, posições e possibilidades.

Todavia, como os homens e as mulheres vivem na História, e como também ao longo das suas vidas mudam as conjunturas que as orientam, e os interesses em causa, a masculinidade hegemônica não se mantêm sempre igual, nem se reproduz ad eternum (ALMEIDA, 2000, p. 243).

Segundo salienta Costa (1992, p. 19), "a construção de subjetividades ideais, implica, ipso facto, a figura da antinorma ou do desvio do ideal, representada pelos que não podem, não sabem ou não querem seguir as injunções ideais".

De constituição e atuação doutrinária, tais afirmações e reafirmações reiteradamente praticadas no que tange às concepções sobre o mencionado centro de referência como posição central e não problemática, desviam nossa atenção do verdadeiro intuito discursivo que as sustenta: o de que são tais deliberações, na verdade e de fato, forjadas enquanto algo natural, permanente e universal. Esquece-se, assim, seu caráter marcadamente construído, como teoriza Oliveira:

Uma ideologia permanece hegemônica enquanto não tem necessidade de ser defendida ou explicada. A eficácia de sua mensagem depende de sua capacidade de produzir um imaginário coletivo, interiorizado por todos e que se identifique com a totalidade do real. Nada escapa a ela, todos têm de agir de acordo com ela. A ideologia pode então permanecer invisível, na medida mesmo em que se reveste de todas as características de uma verdade objetiva, de uma necessidade absoluta, ditada pela ordem natural das coisas (1993, p. 72). 


\section{Bibliografia}

ARRILHA, Margareth; UNBEHAUM, Sandra G.; MEDRADO, Benedito (org). Homens e Masculinidades: Outras Palavras. 1.ed. São Paulo: Editora Ecos 34, 1998.

BARCELOS, José Carlos. Entre o passado e o futuro: Configurações do homoerotismo masculino em narrativas dos anos 50. In: Matagra 17. Revista do Programa de Pós-Graduação em Letras. Rio de Janeiro: Editora Caetés, 2005 (ano 12, número 17).

BARON-COHEN, Simon. Diferença Essencial: A verdade sobre o cérebro de homens e mulheres. Rio de Janeiro: Objetiva, 2004.

BENTO, Berenice Alves de Melo. Da transexualidade oficial às transexualidades. In: Sexualidade e Saberes: Convenções e Fronteiras. Rio de Janeiro: Garamond, 2004.

BERGER, Peter. l; Luckmann, Thomas. A construção social da realidade. 9.ed. Petrópolis: Vozes, 1991.

BRUSCHINI, Cristina; UNBEHAUM, Sandra G. (org). Gênero, democracia e sociedade brasileira. 1. ed. São Paulo: Editora FCC, 2002.

BUSCOTORFF-SILVA, Joaquim M; MIRANDA, Márcio Lopes. Ambigüidade sexual na infância: aspectos cirúrgicos da escolha do gênero na criação. In: Sexualidade e Saberes: Convenções e Fronteiras. Rio de Janeiro: Garamond, 2004.

BUSTOS, Dalmiro M. Manual para um homem perdido. Rio de Janeiro: Record, 2003.

BUTLER, Judith. Corpos que pesam: sobre os limites discursivos do sexo. In: O Corpo Educado: Pedagogias da Sexualidade. 2. ed. Belo Horizonte: Autêntica, 2001.

Problemas de Gênero: Feminismo e Subversão da identidade. Rio de Janeiro: Civilização Brasileira, 2003.

O parentesco é sempre tido como heterossexual. Cadernos Pagu, n. 21, p.219-260, 2003 b.

CAMPOS, Maria Consuelo Cunha. De Frankenstein ao transgênero. Rio de Janeiro: Editora Ágora da llha, 2001.

CARRARA, Sérgio; VIANNA, Adriana, R. B. "As vítimas do desejo": Os tribunais cariocas e a homossexualidade nos anos 1980. In: Sexualidade e Saberes: Convenções e Fronteiras. Rio de Janeiro: Garamond, 2004.

CHAUÍ, Marilena. Repressão sexual, essa nossa (des) conhecida. 5.ed. São Paulo: Editora Brasiliense, 1984.

CIAMPA, Antônio da Costa. A estória do Severino e a história da Severina. 
São Paulo: Editora Brasiliense, 1987.

COUTO, Edvaldo Souza. Corpos modificados - O saudável e o doente na cibercultura. In: Corpo, Gênero e Sexualidade: Um debate contemporâneo na educação. Petrópolis, Rio de Janeiro: Vozes, 2003.

FOUCAULT, Michel. A Mulher/Os Rapazes. 2. ed. Rio de Janeiro: Paz e Terra, 1997.

História da Sexualidade 17. ed. Rio de Janeiro: Editora Graal, 2006.

FURLANI, Jimena. Mitos e Tabus da Sexualidade Humana. 2. ed. Belo Horizonte: Editora Autêntica, 2003.

. Educação sexual: possibilidades didáticas. In Corpo, Gênero e Sexualidade: Um debate contemporâneo na educação. Petrópolis, Rio de Janeiro: Vozes, 2003.

GARCIA, Sandra Mara. Conhecer os homens a partir do gênero e para além do gênero. In: Homens e Masculinidades: Outras Palavras. 1.ed. São Paulo: Editora Ecos 34, 1998.

GOFFMAN, Erving. Estigma: notas sobre a manipulação da identidade deteriorada. Rio de Janeiro: Zahar, 1993.

GREEN, James. N \& POLITO, Ronald. Frescos Trópicos. Rio de Janeiro: Editora José Olympio, 2004.

LOURO, Guacira Lopes. Corpo, escola e identidade. In: Educação e realidade, v.25, jul.- dez., Porto Alegre: (s.e.), 2000, p. 59-76.

----. (org). O Corpo Educado: Pedagogias da Sexualidade. 2. ed. Belo Horizonte: Autêntica, 2001.

-; Neckel, Jane Felipe; GOELLNER, Silvana Vilodre (org). Corpo, Gênero e Sexualidade: Um debate contemporâneo na educação. Petrópolis, Rio de Janeiro: Vozes, 2003.

NOLASCO, Sócrates (1995). O Mito da Masculinidade. 2. ed. Rio de Janeiro: Rocco, 1995.

De Tarzan a Homer Simpson: banalização e violência masculina em sociedades contemporâneas ocidentais. Rio de Janeiro: Rocco, 2001.

O primeiro sexo e outras mentiras sobre o segundo: as questões que mais estão mexendo com a cabeça dos homens. Rio de Janeiro: Best Seller, 2006.

PISCITELLI, Adriana; GREGORI, Maria Filomena; CARRARA, Sergio (org). Sexualidade e Saberes: Convenções e Fronteiras. Rio de Janeiro: Garamond, 2004.

ROHDEN, Fabíola. A obsessão da medicina com a questão da diferença entre os sexos. In: Sexualidade e Saberes: Convenções e Fronteiras. Rio de Janeiro: Garamond, 2004. 
SABAT, Ruth. Gênero e sexualidade para consumo. In: Corpo, Gênero e Sexualidade: Um debate contemporâneo na educação. Petrópolis, Rio de Janeiro: Vozes, 2003.

SIMÕES, Júlio Assis. Homossexualidade masculina e o curso da vida: pensando idades e identidades sexuais. In: Sexualidade e Saberes: Convenções e Fronteiras. Rio de Janeiro: Garamond, 2004.

SPINK, Mary Jane (org). Práticas Discursivas e produção de sentidos no cotidiano. São Paulo: Cortez, 2004.

STOLLER, Robert J. A Experiência Transexual. Rio de Janeiro: Imago, 1982.

-----. Masculinidade e Feminilidade: apresentações do gênero. Porto Alegre; Artes Médicas, 1993.

SULLIVAN, Andrew. Praticamente Normal: Uma discussão sobre o homossexualismo. São Paulo: Companhia das Letras, 1996.

WEEKS, Jeffrey. O corpo e a sexualidade. In: O corpo educado: pedagogias da sexualidade. 2. ed. Belo Horizonte: Autêntica, 2001. 


\title{
TRAVESTIMENTO: LITERATURA, GÊNERO E ESCRITURA \\ TRANSVESTISM: LITERATURE, GENDER AND WRITING
}

\author{
Leandro Júnio Santos Queiroz ${ }^{13}$
}

\begin{abstract}
Resumo:
Este artigo, excerto de minha pesquisa de dissertação de mestrado que investiga a escritura do travestimento homoerótico como representação identitária na literatura brasileira, discorre sobre o conceito de travestimento, utilizado denotativa e metaforicamente na literatura. A roupa e a escrita são tecnologias clássicas, daí nossa abordagem sobre o travestimento físico e literário. Tal conceito é desenvolvido na abordagem das profícuas relações entre literatura, gênero e escritura. Tal como a tecnologia, o gênero é fruto das relações sociais e, portanto, insere-se no contexto da performatividade. Neste sentido, a literatura, tal qual outras artes como o cinema, a teledramaturgia, o teatro e a pintura, podem ser considerados ricos recursos oriundos das mais diversas tecnologias da comunicação, questionando as construções sociais e a normatividade imposta.
\end{abstract}

Palavras-Chave: Travestimento. Literatura. Gênero. Escritura.

\begin{abstract}
:
This article, excerpt from my dissertation research that investigates the homoerotic writing of transvestism as a representation of identity in Brazilian literature, discusses the concept of transvestism denotative and metaphorically used in the literature. The clothing and writing are classic technologies, hence our approach on the physical and literary transvestism. Such a concept is developed in addressing the fruifful relations between literature, gender and writing. As technology, gender is the result of social relations and therefore falls within the context of performativity. In this sense, the literature, like other arts like cinema, soap operas, theater and painting, can be considered rich resources from the most diverse communications technologies, challenging the social constructions and an imposed normativity.
\end{abstract}

Keywords: Transvestism. Literature. Gender. Writing.

\section{Introdução}

O termo "travestimento" costuma ser utilizado para explicar a mudança de identidade de uma personagem quando esta se veste ou se disfarça com roupas do sexo oposto, entretanto, travestir vem a ser, também, o ato de "vestir (-se) para aparentar ser de outro sexo, condição ou idade" ou "[fazer] tomar nova aparência, caráter; transformar (-se)" ou ainda, "tornar irreconhecível; falsificar". (HOUAISS, 2004, p. 732). Não por acaso, o termo 'travesti' é, por extensão, disfarce. Como se sabe o signo 'travesti' está vinculado à noção de sexualidade, muito embora o desejo de travestir-se não

13LEANDRO JÚNIO SANTOS QUEIROZ é mestrando do Programa de Pós-Graduação em Letras/Estudos Literários da Universidade Estadual de Montes Claros - UNIMONTES. E-mail: leosanquez@ hotmail.com 
esteja diretamente relacionado à estimulação sexual. Pode-se travestir por vários motivos que vão desde a realização de uma fantasia até o fetichismo, incluindo-se razões comerciais, humorísticas etc. Deste modo, trabalharemos com outras noções de travestismo e não somente com a ideia do travestimento enquanto manifestação de um desejo homoerótico.

Apesar do auxílio dos dicionários, é muito comum confusão entre os conceitos relacionados à sexualidade. São inúmeras nomenclaturas relacionadas à questão do gênero e que geralmente se tornam confusas. Desta forma, faz-se necessário uma explanação rápida de vários conceitos a serem utilizados aqui para tentarmos não só dirimir dúvidas como clarear nosso campo de estudos. Para tanto tomaremos como base a publicação Manual de Comunicação LGBT (2010), da ALGBT (Associação Brasileira de Lésbicas, Gays, Bissexuais, Travestis e Transexuais) embasado no I Congresso da ABGLT e na I Conferência Nacional LGBT. Comecemos pela relação deste tema com a sexualidade que se refere:

às elaborações culturais sobre os prazeres e os intercâmbios sociais e corporais que compreendem desde o erotismo, o desejo e o afeto, até noções relativas à saúde, à reprodução, ao uso de tecnologias e ao exercício do poder na sociedade. As definições atuais da sexualidade abarcam, nas ciências sociais, significados, ideias, desejos, sensações, emoções, experiências, condutas, proibiÇões, modelos e fantasias que são configurados de modos diversos em diferentes contextos sociais e períodos históricos. Trata-se, portanto, de um conceito dinâmico que vai evolucionando e que está sujeito a diversos usos, múltiplas e contraditórias interpretações e que se encontra sujeito a debates e a disputas políticas. (Manual de Comunicação LGBT, 2010, p. 9). ${ }^{14}$

Salientamos aqui a noção de sexualidade como produto sociocultural sujeito a mudanças, transformações, avanços e retrocessos, acertos e equívocos a partir dos espaços e tempos em que é utilizada.

Travesti é o termo que descreve o indivíduo que obtém prazer, de qualquer tipo, em vestir-se ou disfarçar-se com as roupas do sexo oposto ao seu. Há, portanto, homens e mulheres travestis. Além das vestimentas, costumam usar acessórios e bijuterias do sexo oposto, além de um nome social. Considerando a conotação sexual, os/as travestis são geralmente considerados transgêneros ${ }^{15}$, isto é, aquelas pessoas que transitam entre os gêneros; aquelas cuja identidade de gênero transcende as definições convencionais

14 Disponível em: http://www.abglt.org.br/docs/ManualdeComunicacaoLGBT.pdf. Acesso em: 10 mar. 2011.

15 Quanto ao conceito transgênero, advindo de 'gênero em trânsito', de acordo com Margareth Nepomuceno, "é apresentado como possibilidade dos que cruzam as fronteiras fixas de gênero através de uma tecnologia de si, subjetivada através da corporalidade e da fluidez das sexualidades produzidas". (Disponível em: http://www.fazendogenero.ufsc.br/7/st_16.html. Acesso em: 20 abr. 2011). 
de sexualidade, conforme o Manual de Comunicação $L G B T^{16}$. São considerados transgêneros não somente os/as travestis, mas também os/as transexuais, os transformistas, as Drag Queens, as Drag Kings, os Cross Dressers e os intersex. Embora o travestimento não implique necessariamente em homossexualidade, é comum esta associação. Portanto, faz-se necessário o resgate de alguns conceitos para explanação e, consequentemente, para a ruptura de mitos e "erros". A correlação entre travestimento, literatura, gênero e escritura é, como veremos, inevitável.

\section{Homossexualismo, Homossexualidade, Homoerotismo}

O termo 'homossexualidade' surgiu no século XIX para designar o interesse e a atração sexual por indivíduos do mesmo sexo. Segundo os estudos que se debruçaram sob essa temática, a homossexualidade ao longo da História foi considerada pecado, desvio de personalidade, loucura até o ponto de ser considerada crime e patologia, mais recentemente. No decorrer da História já foi denominada das mais diversas formas: amor maldito, amor que não ousa dizer o seu nome, amor grego, amor antifísico, sodomia, pederastia, pecado nefando, pecado mudo, pecado filosófico, vício abominável, infâmia (no jargão policial), delito contra a natureza, entre outras variantes. A própria ciência ainda não deu conta de esclarecer suas razões ou origens. Certo é que tudo aquilo que ainda não foi bem explicado é alvo de "préconceitos". Basta que se verifique as mais variadas denominações dadas aos homossexuais no decorrer dos anos: sodomita, fanchono, gay, entendido, pederasta, viado, bicha, bichinha, fruta, invertido, pervertido, maldito, uranista, intersexual, missexual, efeminado, traveco, mulher-macho, sapatão etc. Diversas são também as conotações atribuídas ao homoerotismo nos mais variados discursos: anomalia/doença no discurso médico; pecado no discurso religioso; neurose no discurso psiquiátrico; crime no discurso jurídico; perversão no psicanalítico; indecência no senso comum, conforme salienta Jurandir Freire Costa. É ele quem melhor resume:

Nos costumes leigos, científicos ou literários, homossexual e relação homossexual pertencem à gramática da devassidão, obscenidade, pecado, hermafroditismo, promiscuidade, bestialidade, inversão, doença, perversão, falta de vergonha, sadismo, masoquismo, passividade etc. (COSTA, 1992, p. 94).

A crítica e a teoria literárias preferem o emprego do termo 'homoerotismo' e o entende como "uma possibilidade que tem certos sujeitos de sentir diversos tipos de atração erótica ou de se relacionar fisicamente de diversas maneiras com outros do mesmo sexo biológico" (COSTA, 1992, p. 22). O emprego de 'homoerotismo' atende melhor à noção de desejo e

16 Manual de Comunicação LGBT, 2010, p. 17. Disponível em: http://www.abglt.org.br/docs/ManvaldeComunicacaoLGBT.pdf. Acesso em: 10 mar. 2011. 
não necessariamente de sexo como é comum se observar no emprego de 'homossexualismo' ou 'homossexualidade'. Entretanto, há de se considerar que, de acordo com os estudos literários, o homoerotismo envolve todas as relações entre iguais, em todas as suas manifestações, sem que necessariamente ocorra relação física, isto é, carnal entre estes corpos cúmplices. Muitas vezes, o desejo, enquanto impulso sexual ou ambição afetiva pode ser sublimado, interditado ou mesmo impossibilitado. Nem por isso, o desejo homoerótico deixará de existir. Na maioria das vezes, o desejo, no sentido geral, homoerótico ou não, pressupõe ambição amorosa e pode ser manifestado através dos olhares, das carícias, dos movimentos, dos gestos, enfim, da linguagem verbal e corporal. De acordo com Elisabeth Badinter (1993), o desejo homossexual (latente ou não) por si só pressupõe prática homoerótica. Assim, ainda que o desejo afetivo-sexual entre iguais nem sempre seja mútuo, desde que ele ocorra, haverá, portanto, manifestação do homoerotismo.

A presença do homoerotismo na Literatura Brasileira tem se efetivado principalmente a partir de 1970, década em que surge o Movimento Gay. Inclusive, é a partir de 1970 que o tema se consolida efetivamente, apesar do termo 'homossexual' ter sido cunhado desde 1869. A representação ficcional da homoafetividade, termo mais comum no meio jurídico, tem sido amplamente pesquisada, sobretudo após o desenvolvimento dos estudos culturais e de gênero a partir dos anos 1980. A partir de então, os gay's studies e a queer teory entram em franca ascensão. O indivíduo homossexual ainda não é visto como deveria, mas estes estudos contribuem para uma melhor compreensão das sexualidades e que, por isso mesmo, podem proporcionar uma redução do preconceito e da ignorância. Se antes o homoafetivo era visto como perverso ou pervertido, doente ou louco, transgressor ou "anormal", hoje, seu comportamento é, no mínimo, mais discutido e compreendido, razão pela qual já é tão comum a presença de personagens homossexuais em filmes, telenovelas e livros literários, estando presente nos mais diversos meios de comunicação relacionados ou não às tecnologias. Hoje os verdadeiros "crimes contra a natureza" são aqueles que cerceiam vidas, homossexuais ou não, humanas ou não. No entanto, o ser humano ainda não consegue conviver pacificamente com o desejo do outro. A intolerância ainda existe, como se pode observar cotidianamente nos noticiários.

Uma vez que este trabalho também pretende contribuir para uma melhor compreensão do assunto, é preciso esclarecer, imediatamente, a distinção entre os signos "homossexualismo" e "homoerotismo". O primeiro, segundo o francês Michel Foucault e o brasileiro Jurandir Freire Costa, remete ao preconceito homofóbico, vigente no século XIX, ao passo que o segundo recoloca a questão sem homofobia. O psicanalista brasileiro ensina:

Teoricamente, [...], homoerotismo é preferível a "homossexualidade" ou "homossexualismo" porque tais palavras remetem quem as emprega ao vocabulário do século XIX, que deu origem à idéia do "homosse- 
xual". Isto significa, em breves palavras, que toda vez que as empregamos, continuamos pensando, falando e agindo emocionalmente inspirados na crença de que existem uma sexualidade e um tipo humanos "homossexuais", independentes do hábito linguístico que os criou. (COSTA, 1992, p.11).

Pretendendo acabar com a conotação pejorativa de tais termos, Jurandir Freire Costa propõe o emprego de homoerotismo em lugar de homossexualidade. Segundo ele, isso se faz necessário por três razões:

A primeira é de ordem teórica. Devido à obscuridade dos termos convencionais 'homossexualismo' e 'homossexualidade'. Homoerotismo é uma noção mais flexível e que descreve melhor as pluralidades das práticas e desejos humanos. A segunda porque nega a idéia da existência de uma 'substância homossexual' orgânica ou psíquica comum a sujeitos com tendências homoeróticas. A terceira razão porque o termo homoerotismo não possui a forma substantiva que indica identidade, como no caso do 'homossexualismo' de onde derivou o substantivo 'homossexual'. Sendo que o termo homoerotismo admite o entendimento da atração pelo mesmo sexo. (COSTA, 1992, p. 21-22).

Além disso, o sufixo "ismo" é centro de discussões polêmicas que acabam por não defini-lo completamente. Para alguns, entre outros significados, é sufixo de doença, de moléstia, o que implica numa afirmação que a própria ciência ainda não deu conta de esclarecer. Para outros, o sufixo denota 'ciência', o que também não se constitui verdade, uma vez que também não é uma doutrina. O sufixo "ismo" é gradativamente abandonado, surgindo outro: "dade", que significa "um modo de ser". Dessa maneira, homossexualidade é preferivel a homossexualismo e homoerotismo é preferível a homossexualidade. A ABEH (Associação Brasileira de Estudos da Homocultura) e outros setores críticos e de pesquisa recomenda o uso do termo homoerotismo. Assim, o homoerotismo é atualmente compreendido como a atração física, emocional ou até mesmo espiritual entre pessoas do mesmo sexo biológico. Este será o conceito que utilizaremos a partir de agora, estabelecendo as possíveis relações entre este signo e outros como: travestismo, transexualismo, androginia etc..

\section{Travestismo, Transexualismo, Androginia}

Na literatura, o travestimento é frequentemente trabalhado, quer metaforicamente, como artifício escritural, quer denotativamente, como travestimento físico associado ou não às personagens homossexuais. Assim, é possível que, excluindo a conotação sexual, muitos escritores tenham utilizado o travestimento como performance de gênero, na medida em que o prazer 
estaria em macular a figura do homem viril e heterossexual tão idealizado pela cultura machista, falocrática, androcêntrica e patriarcal. Deste modo, é recorrente na literatura a vinculação do homoerotismo à representação identitária e ao travestimento, já que o travestido se encontra no entre-lugar $^{17}$. Não é isso, nem aquilo. É ambíguo, é a própria escritura travestida de corpos que se desejam. Nos jogos eróticos do 'ser' e 'ter', o homoeroticamente inclinado hesita entre ser homem e ter homem. O travesti masculino, por sua vez, hesita entre "ser mulher" e ter homem.

A expressão anterior entre aspas sugere que vai muito além de "ser mulher", razão pela qual alguns estudos discordam dessa visão. Don Kulick, por exemplo, em seu estudo etnográfico de 1998 sobre as travestis de Salvador, afirma que as travestis negam o desejo de adquirir a feminilidade natural das mulheres até porque elas, as travestis, se sentiriam superiores às mulheres por vários motivos. (KULICK, 2008, p. 212). Segundo ele, a expressão "sentirse mulher" entre as travestis tem conotação negativa, referindo-se àquelas que teimam em ir contra um fato: travestis não são mulheres nem nunca serão. Nem mesmo buscam, conforme Kulick, uma subjetividade feminina porque poderiam se sentir superiores umas às outras, como ocorre com as mulheres, no ponto de vista travesti. Por esse motivo, no dizer de Kulick, as travestis estariam constantemente relembrando sua masculinidade e não se definiriam nem como homens nem como mulheres, reivindicando o título de homossexuais autênticos, realmente "assumidos". Elas são descritas, muitas vezes, como "homens com peito" ou "mulheres com pau", comenta Kulick, ou se autodenominam "mulheríssimas" porque seriam 'mais mulheres' que as próprias, afinal podem vivenciar as duas fases: masculina e feminina. As muIheres, não; estas seriam 'apenas mulheres'. (KULICK, 2008, p. 203). Contudo, a subjetividade travesti não é tão simples, pois,

mesmo vestidas de homem, elas não são homens de fato; as travestis não se consideram 'homens' (declaram para quem lhes perguntar e reafirmam para si mesmas constantemente esta idéia), mas homossexuais, isto é,

17 Entre-lugar é um construto teórico criado por Silviano Santiago em seu ensaio "O entre-lugar do discurso latino-americano" presente em Uma literatura nos trópicos (1978). Amplamente utilizado na discussão dos Estudos Culturais, o conceito refere-se às "políticas" críticas de deslocamento, descentramento e desconstrução. Assim, tal conceito abarca as identidades em trânsito e os discursos de transição, fronteira e marginalização, incluindo-se as minorias. Aqui, salientamos que o sujeito travestido se encontra no entre-lugar por estar entre o masculino e o feminino, não aparentando completamente nem um nem outro. Além disso, por estarem contrários às normas culturais e sociais impostas (heteronormatividade, machismo, patriarcado), os homossexuais (travestidos ou não) são tidos como queers e considerados marginais (à margem da sociedade), outsiders (fora da lei/norma), "diferentes" e "deficientes". Assim, a figura do travesti se encaixa neste universo da travessia/fronteira/margem/transição de um gênero para outro, de uma identidade para outra. Neste trabalho muitos são os entre-lugares a que nos referimos: ficção e realidade, memória e invenção, verdade e mentira, sagrado e profano, bem e mal, autor e leitor, homossexualidade e heterossexualidade, masculino e feminino, amor e amizade, vida e morte, entre outros. E como aponta Denilson Lopes, frágeis e ambíguas são as fronteiras entre homossexualidades e heterossexualidades. (LOPES, 2001, p. 39). "O entre-lugar das homoafetividades está entre identidades, entre homo e heterossexualidades, implica repensar as masculinidades para além de uma homossociabilidade homofóbica." (LOPES, 2001, 46). Tal qual o travestimento, a escrita também apresenta esse caráter de entre-lugar, uma vez que há uma indecidibilidade do travestimento (homem e mulher) e da escrita (técnica e arte). 
"viados", bichas. O núcleo duro de sua subjetividade é o fato de sentirem atração física e sexual por homens. [...] O desejo homossexual é, portanto, a tendência que baliza e dá sentido às práticas corporais, às atividades profissionais e aos relacionamentos afetivos das travestis. Ser homossexual está no âmago do projeto travesti. Para que uma pessoa seja travesti, ela deve primeiro ser "viado". [...] a subjetividade travesti não é a subjetividade de mulher nem a subjetividade de homem, é a subjetividade de um efeminado de sexo masculino - um homossexual. (KULICK, 2008, p. 230-231).

Mas as travestis não são somente homossexuais, vão além: legítima, autêntica e integralmente homossexuais ou, como prefere Kulick, "perfeitamente homossexuais". Na opinião delas mesmas, as travestis são os "únicos homossexuais realmente 'assumidos' no Brasil". (KULICK, 2008, p. 231). A pesquisa de Kulick, no entanto, é sobre as travestis masculinas que se prostituem e que se assumem como "verdadeiros homossexuais". Na visão travesti, aponta Kulick, os outros homossexuais (não-travestis) seriam covardes, pois não assumiriam verdadeiramente sua homossexualidade como elas o fazem. Assim, na visão das travestis, o verdadeiro homossexual é aquele que não só é homossexual, mas se assume publicamente como tal, travestindo-se inclusive. Os homossexuais não travestidos, embora tenham a mesma inclinação homoerótica de muitas travestis, se escondem, se disfarçam e fingem que são homens, quando na verdade não são.

Nos depoimentos das travestis de Salvador, transcritos por Kulick, destacam-se os relatos de homens viris que manteriam relações sexuais com elas preferindo ser insertados ${ }^{18}$. Como no Brasil, diferentemente da Europa e dos Estados Unidos, como mostra Kulick, a noção de 'ser homem' e/ou 'ser mulher' está fortemente associada à genitalidade e penetração, isto é, 'ser homem' no Brasil é ter pênis e ser somente ativo e 'ser mulher' é ter vagina e ser somente passiva, qualquer pessoa que infrinja essas "normas" ou regras culturais estariam imediatamente vinculadas à homossexualidade. (KULICK, 2010, p. 221). No Brasil, o homem insertado assim como o efeminado é considerado gay 19 , tal qual a mulher "dominadora" e de comportamentos viris. Neste sentido é que as travestis se consideram homossexuais mais honestos, porque se assumem como tais o tempo todo e não somente entre quatro paredes, às escondidas e na calada da noite. (KULICK, 2008, p. 233).

São essas definições de papéis, se ativo ou passivo, que acabam por determinar o "gênero" e a orientação sexual em nossa cultura. Em outras palavras,

a definição de gênero implica espontaneamente a sexualidade: quem faz o que, e com quem? A identidade

18De acordo com Kulick (2008) são frequentes os comentários entre as travestis-prostitutas de que alguns de seus clientes preferem ser passivos nas relações sexuais com elas. Muitos ainda fazem questão de que elas tenham genitais de comprimento e circunferência acima da média.

19 Contemporaneamente, a denominação 'gay' se refere tanto ao homossexual masculino quanto ao feminino. Ou seja, é usual para homens e mulheres homoeroticamente inclinados. Já a denominação 'lésbica' se refere apenas à homossexual feminina. 
masculina está associada ao fato de possuir, tomar, penetrar, dominar e se afirmar, se necessário pela força. A identidade feminina, ao fato de ser possuída, dócil, passiva, submissa. "Normalidade" e identidades sexuais estão inscritas no contexto da dominação da mulher pelo homem. (BADINTER, 1993, p. 99).

Seguindo este raciocínio, é que a homossexualidade seria considerada anormalidade, doença mental ou perturbação da identidade de gênero, segundo Badinter, uma vez que implicaria em dominação de um homem por outro. (BADINTER, 1993, p. 99). Assim, a masculinidade, na visão tradicional, só existiria naqueles homens que detivessem as seguintes características: viril e dominador (extremamente), forte e possessivo (geralmente), ativo (em todos os sentidos), violento (se necessário) e heterossexual.

Falamos a pouco das relações entre as travestis prostitutas e seus clientes. Há de se esclarecer, no entanto, que nem toda travesti se prostitui20 e que não há relação direta entre travestimento e homoerotismo, isto é, o travesti não é necessariamente um sujeito homoerótico, podendo ser homo -hétero-bi-assexual ou qualquer outra denominação sistemática. Inclusive, é justamente essa sistematização categórica que tem provocado segregação, discriminação, confusões e suas consequências. Mas, afinal, o que caracteriza a identidade travesti?!

De acordo com o Manual de Comunicação LGBT, o transformista é o indivíduo que se veste com roupas do gênero oposto movido por questões artísticas. Assim, o transformista é tão somente o performer que se veste com roupas do sexo oposto para apresentar uma performance, masculina ou feminina, durante um espetáculo. Geralmente são artistas que interpretam ou imitam personalidades do sexo oposto. O fato de se vestir do sexo oposto não implica necessariamente em inclinação homoerótica, uma vez que seus intuitos são essencialmente artístico-comerciais. Isso não quer dizer que não possa existir o transformista homoeroticamente inclinado e que se satisfaça sexualmente com tal performance. Na visão das próprias travestis, como relata Kulick, o que as difere dos transformistas é o fato deste último ser um homem que apenas se veste como mulher, enquanto elas são homens que vivem as 24 horas do dia como mulheres. (KULICK, 2008, p. 215)

Quanto às drag queens, o Manual de Comunicação LGBT explica que o termo refere-se ao "homem que se veste com roupas femininas de forma satírica e extravagante para o exercício da profissão em shows e outros eventos". ${ }^{21}$ Conforme o Manual, uma drag queen não deixa de ser um tipo de "transformista", pois o uso das roupas está ligado a questões artísticas - a diferença é que a produção necessariamente focaliza o humor, o exagero. Daí o fato de elas serem foco da Estética Camp. Quanto aos drag kings, o Manual informa que é a versão "masculina" da drag queen, isto é, trata-se de uma mulher que se veste com roupas masculinas para fins profissionais.

20 Além da prostituição, vários outros estigmas são dados às travestis, tais como: homossexualidade, drogas, AIDS, espalhafato, exagero, exotismo, escândalo, violência, agressividade etc.

21 Manual de Comunicação LGBT, 2010, p. 16. Disponível em: http://www.abglt.org.br/docs/ManvaldeComunicacaoLGBT.pdf. Acesso em: 10 mar. 2011. 
Deste modo, conforme explica Hélio Silva em Travesti: a invenção do feminino, as travestis se distinguem das/dos drags em alguns aspectos: utilizam próteses de silicone e hormônios na constituição de seus corpos, geralmente passam todo o dia transformados/montados ou travestidos e, também geralmente, não se expõem de maneira caricata. (SILVA, 1993).

Já os crossdressers (ou CDs) são os praticantes do crossdressing, considerada uma forma de travestismo. No sentido literal significa vestir-se ao contrário. O termo foi criado para afastar-se das conotações negativas da denominação 'travesti', ou seja, para evitar as estigmatizações deste segundo termo: drogas, prostituição, homossexualidade, violência, espalhafato, exagero etc. Os cross dressers são "pessoas que, regular ou ocasionalmente, usam roupas que socialmente são vistas como sendo usadas por pessoas do sexo oposto. Geralmente estas pessoas sentem-se bem com o seu sexo biológico e não querem mudá-lo". ${ }^{22}$ A maioria dos crossdressers assume-se como heterossexuais; alguns, no máximo, bissexuais. Há crossdressers masculinos, aqueles que se travestem de mulheres, e crossdressers femininos, aqueles que se travestem de homens. De acordo com o vocabulário LGBT, quando os crossdressers masculinos não estão "montados"23, isto é, vestidos de muIher, são chamados de "sapos". Quando já "montados" são chamados de "princesas".

Contudo, a maior confusão ocorre mesmo no emprego dos termos "travestismo" e "transexualismo". De acordo com o Manual de Comunicação LGBT, diferentemente das transexuais, as travestis não desejam realizar a cirurgia de redesignação sexual (mudança de órgão genital) ${ }^{24}$, mas muitas travestis modificam seus corpos por meio de hormonioterapias, aplicações de silicone e/ou cirurgias plásticas, embora isso não seja regra para todas ${ }^{25}$. Quanto às transexuais, o mesmo Manual afirma que são pessoas que possuem uma identidade de gênero diferente do sexo designado no nascimento e que homens e mulheres transexuais podem manifestar o desejo de se submeterem a intervenções médico-cirúrgicas para realizarem a adequação dos seus atributos físicos de nascença, inclusive genitais, a sua identidade de gênero constituída. Diferentemente do que se imagina, a cirurgia de redesignação sexual não corta órgão algum, mas o transforma. O pênis é imbutido, transformando-se numa vagina. É comum ouvir das transexuais que elas nasceram num corpo errado, já que mente e corpo não são consonantes. Entre as travestis há a crença de que a cirurgia de redesignação sexual promoveria a perda da libido, do prazer sexual; daí o fato delas recusarem a cirurgia. Além disso, para aquelas travestis que se prostituem, muitos clientes

22 Glossário LGBT. Disponível em: http://www.rea.pt/glossario.html. Acesso em: 08 fev. 2011.

23 Montagem e desmontagem são termos técnicos muito utilizados entre as travestis, drag queens e drag kings, transformistas, crossdressers, entre outros, para referir-se ao ato de vestir-se e paramentar-se com roupas e acessórios típicos do sexo oposto.

24 De acordo com Berenice Bento (2008), a cirurgia de transgenitalização é também conhecida como mudança de sexo, redesignação sexual, readequação sexual e cirurgia corretiva e faz parte do processo transexualizador, que possibilita aos sujeitos transexuais a passagem do gênero atribuído para o identificador.

25 Manual de Comunicação LGBT, 2010, p. 18. Disponível em: http://www.abglt.org.br/docs/ManvaldeComunicacaoLGBT.pdf. Acesso em: 10 mar. 2011. 
só as procuram pelo fato de elas possuírem genitália masculina em um corpo com características femininas. "Mulheres" fálicas, portanto.

Quanto ao fenômeno do transexualismo ${ }^{26}$, nos anos 1980 é que o termo 'transexualidade' é incluído entre os distúrbios de identidade de gênero e seu adjetivo, transexual, pode ser utilizado tanto para homens quanto para as mulheres que possuem um corpo, um nome e uma situação social nãocondizentes com o seu estado psíquico/emocional, afinal seu sexo genital/ biológico/anatômico é contrário ao seu autorreconhecimento de gênero. Com relação a essas distinções, em um minucioso estudo etnográfico/antropológico sobre as travestis e transexuais do Rio Grande do Sul, intitulado Toda Feita: o corpo e o gênero das travestis, é Marcos Renato Benedetti quem esclarece:

os principais fatores de diferenciação entre uma figura e outra se encontram no corpo, suas formas e seus usos, bem como nas práticas e relações sociais. [...] Travestis são aquelas que promovem modificações nas formas do seu corpo visando a deixá-lo o mais parecido possível com o das mulheres; vestem-se e vivem cotidianamente como pessoas pertencentes ao gênero feminino sem, no entanto, desejar explicitamente recorrer à cirurgia de transgenitalização para retirar o pênis e construir uma vagina. Em contraste, a principal característica que define as transexuais nesse meio é a reivindicação da cirurgia de mudança de sexo como condição sine qua non da sua transformação, sem a qual permaneceriam em sofrimento e desajuste subjetivo e social. (BENEDETTI, 2005, p. 18).

Benedetti em sua etnografia sobre "as práticas sociais de construção do gênero observadas num caso radical de transformação corporal e social: as travestis que se prostituem em Porto Alegre" durante o período de 1995 a 1999 esclarece que, de qualquer forma, o travesti não tem interesse em mudar seu sexo, aceitando bem seus genitais, diferentemente dos transexuais que não aceitam seu sexo, sua identidade, seu nome, sua condição. Segundo ele, as travestis se sentem e se expressam publicamente de forma feminina, mas sem abrir mão de alguns atributos masculinos em algumas relações que estabelece com a sociedade.

Alguns estudos mais radicais, como Almeida (1999) e Silva (1999), apontam que as transexuais acreditam que suas almas ou personalidades habitam em corpos errados porque possuem sexo biológico/anatômico não condizente com sua orientação sexual; que desejam parceiros heterossexu-

260 transexualismo ainda é classificado como patologia desde 1970. Segundo o Código Internacional de Doenças (CID), trata-se de uma "disforia de gênero" que se caracteriza por uma incongruência entre o sexo genital e o gênero. Isso levaria o indivíduo transexual a buscar incessantemente a adequação dessas categorias por meio de operação da genitália. Tanto o DSMIV quanto a CID-10 classificam o travestismo e o transexualismo como transtornos de identidade de gênero. Essa patologização das categorias transexual e travesti é discutida por Jorge Leite Júnior em sua tese de doutorado 'Nossos corpos também mudam': sexo, gênero e a invenção das categorias travesti e transexual no discurso científico (2008). 
ais; rejeitam a homossexualidade e, durante os atos sexuais, comportam-se da maneira como se sentem apenas (homens ou mulheres), não costumam olhar nem mesmo tocar os próprios genitais; não sentem atração pelo mesmo sexo; não convivem em guetos; além de desejarem a cirurgia transgênero (advindo de 'transformação de gênero'). Por outro lado, os mesmos estudos afirmam que as travestis têm comportamentos bissexuais e homossexuais; usam adereços femininos para trabalhar na prostituição; geralmente sentem atração pelo mesmo sexo; assumem papéis masculinos e femininos durante o ato sexual; vivem em guetos, onde são aceitos com mais facilidade e não desejam, de forma alguma, submeter à cirurgia de redesignação sexual.

Além de Benedetti (2005), outros estudos como os de Couto (1999), de Oliveira (1994) e Kulick (2008) afirmam que a característica mais comumente associada à transexual é a da cirurgia de adequação sexual como condição primordial para sua transformação. Nem todos os estudos concordam com essa visão. Para estudos mais recentes, a cirurgia de redesignação sexual não é condição imprescindível para a transexualidade; é apenas a parte final de um longo processo de transformação de gênero. Por este motivo, considera-se que o sujeito transexual nasça transexual, necessitando apenas da cirurgia de readequação genital para harmonizar sua identidade sexual (física) à sua identidade de gênero (psíquica). Por esse motivo, os indivíduos transexuais que ainda não realizaram a referida cirurgia corretiva são considerados transexuais pré-operados.

Contudo, o que parece ser unânime nos estudos sobre travestivismo é a questão das subjetividades. Dos estudos investigados, todos concordam numa tentativa de definição das travestis e transexuais a partir da análise de suas subjetividades. Mas afinal, que subjetividades comporiam a identidade travesti?! No sistema binário de gênero, como as travestis poderiam se encaixar, se não são nem uma coisa, nem outra?! Fariam parte, então, de um terceiro sexo como muitos já propuseram?!

Don Kulick explica que o cabelo, marca patente de feminilidade, é muitas vezes, nas brigas entre as travestis, cortado a tesouradas irregulares. A travesti sem o cabelo fica despojada de feminilidade e, portanto, humilhada diante de outras, pois seu lado masculino, tão negado e escondido, é "vergonhosamente" exposto. Como coloca Kulick, "privada do artifício (cabelo, vestido), ela é terminantemente um homem", então, "umas poucas tesouradas bem desferidas são o suficiente para converter uma travesti de bela mulher em andrógino feioso". (KULICK, 2008, p. 215). Mas por que andrógino?! Ora, o andrógino é aquele que nem é totalmente masculino nem completamente feminino. Assim, travestis seriam seres andróginos? Pertenceriam, então, ao tal terceiro gênero?! Haveria um gênero travesti? Kulick discorda dessa tripartição de gêneros: "as travestis, de fato, não se consideram homens nem mulheres (...) e referem-se usualmente a si mesmas como 'bichas' e 'viados'. No entanto, eu nunca ouvi, durante toda a pesquisa, qualquer sugestão vinda delas de que pudessem formar um terceiro gênero ou um terceiro sexo". (KULICK, 2008, p. 236). 
E discorda também de vários estudos sobre as travestis quando estes as analisam pelo viés da ambiguidade (Arnaldo Jabor, 1993 e Hélio Silva, 1993) ou da diferença (Neuza Maria de Oliveira, 1994). Kulick renega as ideias de que as travestis aspirariam a ser mulheres, de que seriam seres inclassificáveis e de que seriam "andróginos pós-modernos" ou, em suas palavras,

assim como as travestis não estão lutando para conquistar a condição de mulher (womanhood, em inglês), elas também não rejeitam a identidade e também não desejam a ambiguidade. Sua luta - e elas deixam isso claro para quem quiser ouvir - é pela homossexualidade. Elas almejam incorporar a homossexualidade. E desejam fazer isso da maneira mais completa, mais perfeita e mais bela possível. Ao passo que outros indivíduos do sexo masculino denegam e disfarçam o desejo pelo mesmo sexo, as travestis abraçam este desejo e se deliciam com ele. A vida delas é ancorada nesse desejo. O corpo delas é fabricado em função desse desejo. (KULICK, 2008, p. 233).

Todavia, como nos interessa, aqui faremos uso dessa noção de dubiedade impressa no universo travesti e concordaremos com Jabor (1993) e Silva (1993), afinal, como salientamos em nossa introdução, este trabalho visa a defesa do argumento de ambiguidade do/no corpo e da/na escrita, daí o fato de utilizarmos propositadamente a oscilação de gênero, vacilando entre o masculino e o feminino, empregando as duas concordâncias. Para tanto desenvolveremos a noção de androginia.

A androginia ${ }^{27}$ é a mistura de características masculinas e femininas num mesmo ser, ou seja, aquele que não é nem masculino nem feminino completamente. De acordo com o Manual de Comunicação LGBT, a androginia é o termo genérico usado para descrever qualquer indivíduo que assuma postura social, especialmente a relacionada à vestimenta, comum a ambos os gêneros ${ }^{28}$. Assim, conceberemos o/a travesti, ainda que metaforicamente, a partir de agora, como um ser andrógino, já que a travesti dificilmente é vista ou compreendida apenas como mulher ou apenas como homem. Para a psicologia, a androginia é uma disforia de gênero rara, mas ainda não consta da CID (Classificação Internacional de Doenças). Por seu caráter híbrido, os andróginos possuem características físicas e comportamentais de ambos os sexos. Por esse motivo fica difícil definir o gênero de um andrógino apenas por sua aparência. Para ressaltar a dualidade, os andróginos, geralmente, se ornam e se vestem com adereços e roupas de ambos os sexos. Entretanto, segundo os estudos médicos e psicológicos, a androginia não tem relação com a "orientação sexual", isto é, pode haver andróginos heterossexuais, homossexuais, bissexuais, assexuais etc. Este caráter dual do androginismo é reforçado também por Badinter que afirma que "machos e fêmeas só se tornam plenamente humanos no androginato, que só pode ser

27 Segundo sua etimologia grega: anér-andrós = "homem" e gyné-gynaicos = "mulher".

28 Manual de Comunicação LGBT, 2010, p. 16. Disponível em: http://www.abglt.org.br/docs/ManvaldeComunicacaoLGBT.pdf. Acesso em: 10 mar. 2011. 
duplo." (BADINTER, 1993, p. 166). Segundo Badinter, o andrógino é duplo, é uma mistura de homem e mulher, mas, segundo ela, isso não significa que o andrógino seja um ser dotado dos dois sexos.

Mas o que nos interessa é a noção de ambiguidade, de dubiedade presente em alguns conceitos. A própria noção de gênero também está pautada no dualismo: ou se é um ou se é outro. Basta lembrarmo-nos dos binarismos culturais: masculino/feminino; homem/mulher; macho/fêmea. Ou seja, não há meio termo, ou se é algo ou o contrário. A teoria queer e a estética camp, do qual falaremos adiante, vêm para questionar essas fronteiras da sexualidade. Haverá mesmo margens no que tange ao gênero? Conforme apontamos, o fetichismo transvéstico, masculino ou feminino, não implica no fato de o sujeito travestido ser ou não gay ${ }^{29}$. Isto é, como dissemos, a chamada "orientação sexual" não tem uma relação direta com o travestismo, de modo que é incorreto associar genericamente o travestismo à homossexualidade. O que se deve levar em consideração são os motivos que levam o sujeito a se travestir ou que desejos, em todas as acepções do termo, a pessoa pretende satisfazer. Isso porque não se pode afirmar genericamente que os indivíduos travestidos e outros transgêneros se ornamentam ou se vestem com roupas do sexo oposto apenas por questões sexuais. Afinal, o travestimento pode ser ocasional, como no caso dos homens que se fantasiam de mulheres no carnaval. Não deixam de ser/estar indivíduos travestidos, porém não se comportam dessa maneira por estimulação sexual. Como popularmente se afirma, todo ser humano deve descobrir "seu outro lado" ou "o homem/a mulher que habita em si".

Deste modo, o travestismo é uma questão de gênero, não de sexo. Conforme esclarece Benedetti (2005), o sexo se refere ao nível físico; gênero, por sua vez, é denominação concernente ao nível simbólico. Neste caso, a virilidade, por exemplo, é um atributo de gênero, não de sexo. Segundo John H. Gagnon, o desejo é pelo gênero de uma pessoa (isto é, o complexo socialmente construído de masculinidade ou feminilidade) e não por seu sexo biológico. E é justamente o fato de o desejo ser um construto sociocultural e não um produto meramente biológico que explica a atração afetiva ou sexual pelo gênero das pessoas e não pelo seu sexo. (GAGNON, 2006, p. 161). Assim, expressões como 'orientação sexual', "opção sexual" e 'preferência sexual' só corroboram com a incompreensão do homoerotismo, na medida em que não se é orientado e não se escolhe uma sexualidade, seja ela qual for. Ainda que a ciência não tenha comprovado a origem ou as razões para a homoafetividade, sabe-se, ao menos, que o desejo é inato ao ser humano. Como bem coloca o Manual de Comunicação LGBT, gênero é um conceito formulado nos anos $1970 \mathrm{com}$ profunda influência do movimento feminista e foi criado para distinguir a dimensão biológica da dimensão social, baseando-se no raciocínio de que há machos e fêmeas na espécie humana ${ }^{30}$. No entanto, explica o Manual, a

29 Novamente utilizamos aqui a concepção contemporânea de gay, isto é, como homossexual masculino e/ou feminino.

30 Manual de Comunicação LGBT, 2010, p. 9. Disponível em: http://www.abglt.org.br/docs/ManualdeComunicacaoLGBT.pdf. Acesso em: 10 mar. 2011. 
maneira de ser homem e de ser mulher é realizada pela cultura. Judith Butler, umas das teorizadoras da Teoria Queer ressalva:

Se o caráter imutável do sexo é contestado, talvez essa construção chamada sexo seja também construída culturalmente, assim como o gênero. Talvez, quem sabe, o sexo tenha sido sempre gênero e, em consequência, a distinção entre sexo e gênero seja inexistente. (BUTLER, 1990, p. 6-7).

Desta forma, para a teórica, sexo não determina o gênero. São ambos produtos culturais. Portanto, enquanto o sexo biológico é o "conjunto de informações cromossômicas, órgãos genitais, capacidades reprodutivas e características fisiológicas secundárias que distinguem machos e fêmeas"; gênero "significa que homens e mulheres são produtos da realidade social e não decorrência da anatomia de seus corpos." ${ }^{1}$. O gênero é cambiável, mutável; o sexo é biológico, fisiológico e a identidade, assim como o gênero, é transitável, isto é, está constantemente em trânsito.

Neste sentido, desejo e escrita podem ser correlacionados na medida em que gênero e linguagem, bem como corpo humano (corpo do homem) e corpo escrito (corpo da escrita), possuem entre si profundas analogias. Sexo é algo dado, imposto pela natureza. O gênero, por sua vez, pode ser transformado a qualquer momento. A experiência transgender, por exemplo, ratifica este caráter artificial e fabricado do gênero. Assim também ocorre com a linguagem.

\section{O desejo e a escrita}

O exercício da escrita, a escritura, nascido da subjetividade do escritor, do desejo de escrituralidade, permite que o desejo pelo parceiro do mesmo sexo assuma corpo no texto. Como estamos tomando a narrativa como corpo escrito são as relações óbvias e fecundas entre corpo e desejo que nos permitirão, aqui, estabelecer uma analogia entre desejo e escrita. $O$ corpo no qual se deixa inscrever qualquer coisa em si é também o corpo da narrativa. $O$ corpo travestido traz em sua superfície o que mais caracteriza o corpo homoerótico: o seu desejo. Desejo pelo semelhante, pelo mesmo sexo.

Seguiremos, aqui, a concepção lacaniana de desejo, ou seja, o desejo enquanto impulso, atração, enquanto necessidade de satisfação afetiva e/ou sexual. O desejo, na conotação sexual, nada mais é que o impulso erótico que motiva nossa atenção, empenho e cobiça (também desejo) pelo outro. E o erótico, como sugerem Roland Barthes e Octavio Paz, é o mostrar-se escondendo, como faz a escrita. No entanto, afastada a conotação erótica, desejo também pressupõe vontade, querência, ambição, propósito.

31 Manual de Comunicação LGBT, 2010, p. 9. Disponível em: http://www.abglt.org.br/docs/ManualdeComunicacaolGBT.pdf. Acesso em: 10 mar. 2011. 
Desejar é apetecer, desejar ardentemente é almejar, cobiçar. Neste sentido, também faremos uso dessas conotações de desejo, uma vez que pretendemos discorrer não somente sobre o desejo homoerótico, mas principalmente sobre o desejo do escritor de travestir sua vida em escrita.

Tanto o corpo biológico quanto o corpo escrito podem ser "lidos" como físicos, desejados e textuais; carregados de significantes, subjetividades e signos de superfície, ambos são manipuláveis, alvos da (des)montagem de seus admiradores. Travesti e Texto são corpóreos, desejáveis e alteráveis a qualquer tempo e espaço, sempre passíveis do desejo e da escrituralidade. Neste sentido, corpo biológico e corpo escrito engendram um desejo da escrita e uma escrita do desejo. Fruto da modernidade, a relação entre desejo e escritura/corpo e linguagem se explicita na tessitura, no corpo da narrativa. Todo escritor guarda um patente desejo: o de criação de sua escritura/ literatura, afinal há na literatura um constante desejo: o desejo da escritura.

De acordo com Bruno Moreto (2008), múltiplos desejos podem ser ativados na obra literária no momento de sua leitura: o desejo como organizador textual, o desejo do narrador, o desejo das personagens e o desejo do leitor. "O ato de leitura ativa o processo desejante: assim sendo, a interpretação desvelaria o desejo atuante contido no texto, bem como o desejo do leitor; dessa forma, o texto carece do leitor para poder desejar. Só assim a ficção se estabelece por completo." (MORETO, 2008, p. 13). Em O prazer do texto, Barthes afirma que a escritura é a prova de que o texto deseja o leitor. Conforme Moreto, escritura e leitura são dois processos em que o desejo se impõe. Para fundamentar seu raciocínio, cita Cleusa Rios Pinheiro Passos que afirma:

Tal desejo, provável máscara de outros - inconscientes - encontrou, no texto literário, "espaço de ilusão", fruto de dois momentos básicos, sempre ligados na obra, nem sempre, porém, delineados com precisão: o da escritura, tecido que se faz e engendra significações, e o da leitura, eco, espelho - superfícies lisas -, mas também caixa de ressonância, espaço de sons que se cruzam e ressaltam: desejos. (PASSOS, apud MORETO, 2008, p. 13).

Gilles Deleuze costumava dizer que o desejo é um ato revolucionário. Considerando a heteronormatividade universal, nada mais revolucionário e transgressor que o desejo homoerótico. Aqui, entre outras manifestações de desejo, focaremos no desejo homoerótico, isto é, no desejo estabelecido nas relações entre iguais. Desejando explicar o desejo homoerótico e tentando desconstruir as noções de "orientação sexual" e "preferência sexual", John H. Gagnon, argumenta que, além de desejarmos o gênero das pessoas e não seu sexo, esse desejo é socialmente construído e não biologicamente impulsionado, assim como "preferimos" o outro e não somos orientados para o outro. Essa preferência, segundo Gagnon, é instável e mutável ao longo da vida e tal instabilidade tanto pode ser interna (o que desejamos na outra pessoa muda) quanto externa (podemos vir a desejar pessoas do outro gênero, assim como pessoas do mesmo gênero). E ainda, nem todas as prefe- 
rências sexuais são preferências relacionadas ao gênero, isto é, podemos ter preferências raciais, técnicas etc. (GAGNON, 2006, p. 162).

Tomando como base os raciocínios de Gagnon (2006) e os estudos de Costa (1992) e Lacan (1978), para quem o desejo do homem é o desejo do Outro, apontaremos aqui três formas de manifestação do desejo: 1 - o desejo de travestir a vida em escrita (desejo da vida escrita) e o desejo em se travestir (desejo de ser/parecer/pertencer ao sexo oposto): TRAVESTIMENTO da escritura/homoerótico; 2 - o desejo de reconhecimento e valorização de uma identidade (desejo de ser/se afirmar): IDENTIDADE; 3 - o desejo homoafetivo e homoerótico (desejo afetivo/pulsão sexual): HOMOEROTISMO.

Perceba que todas essas manifestações de desejo aqui apontadas estão imbricadas, harmoniosamente mescladas. Entretanto, assim como a identidade de gênero é uma construção sociocultural ou um "produto da linguagem", o desejo erótico/homoerótico também o é. Neste sentido é que Costa afirma:

Não existe objeto sexual "instintivamente adequado ao desejo" ou vice-versa, como reitera a psicanálise. Todo objeto de desejo é produto da linguagem que aponta para o que "é digno de ser desejado" e para o que "deve ser desprezado" ou tido como indiferente, como incapaz de despertar excitação erótica. (COSTA, 1992, p. 28).

Assim, é pelo fato de o desejo (homo)erótico ser um produto sociocultural que abre-se espaço para o questionamento da normatividade a partir de identidades várias. Entre as que nos interessa, apontamos a sexual, a social e esta última em contraposição com o papel social de gênero.

\section{Identidades: sexual, social e de gênero}

Existem inúmeras formas de identidade e diferentes visões sobre ela, afinal, as próprias identidades são produtos históricos e socioculturais. Os estudos falam basicamente de dois modelos identitários: o essencialista e 0 construtivista. No primeiro somos aquilo que nascemos, no segundo somos aquilo em que nos transformamos. O primeiro modelo salienta que a identidade é genética e, portanto, determinada pela natureza e o segundo afirma que a identidade é construída e transformada durante nossas vidas.

A primeira identidade a que pertencemos é a identidade de gênero, isto é, ser homem ou mulher. Como isso é cultural, ou se é uma coisa ou outra. Não há meio termo. É aí que residem os conflitos, pois, há, por exemplo, o caso dos homossexuais. Sexualmente, nascem homens ou mulheres, mas nem sempre sentem-se/afirmam-se/reconhecem-se como homens ou muIheres. Alguns estudos apontam para uma identidade fixa e que só seria mutável o papel social correspondente a essa identidade. Aqui ficaremos com a teoria queer sobre a identidade homoerótica que atribui às identidades 
(várias) o caráter de mutáveis e infinitas.

No dizer de José Carlos Barcellos, é a partir dos anos 1960 e 1970 que surge a emergência de uma identidade gay. (BARCELLOS, 2006, p. 27). Em A Inocência e o Vício: estudos sobre o homoerotismo, Jurandir Freire Costa (1992) ressalta que a identidade sexual é um produto cultural e distingue, a partir de outros autores, os quatro estágios de aquisição dessa identidade. Para ele, a identidade homoerótica perfaz quatro estágios: sentir-se diferente; dar sentido (significado) a essa diferença; reconhecer-se pelo outro e posteriormente ter aceitação de si mesmo. Salienta que nem todo indivíduo obrigatoriamente chega ao último e que a prática sexual entre homens por si já carrega a identidade do sujeito de aspectos afeminados. Isso se explicaria, em parte, porque numa relação homoafetiva masculina, os homens envolvidos jamais se considerariam como "homens de fato", sugere Costa. Segundo ele, esta desvalorização das/nas relações homoeróticas seria explicada justamente pela incapacidade de reprodução.

No dizer de Elisabeth Badinter em seu livro XY: sobre a identidade masculina, os homens, hoje, padecem da fragmentação deles mesmos. (BADINTER, 1993, p. 125-126). Consequência, segundo ela, do sistema patriarcal que pôs no mundo um homem mutilado, incapaz de reconciliar $X$ e $Y$, suas heranças paterna e materna. $O$ homem está dividido em dois, dividido entre ser macho (seu exterior hostil e viril) e ser fêmea (seu interior ameno provocado pelo contato com a mãe). Ademais, de acordo com Badinter, são os próprios homossexuais que criam a problemática identificatória, pois querem que seja reconhecida sua especificidade, ou seja, o que hoje chamaríamos de direito à diferença. (BADINTER, 1993, p. 102-103). Isso se dá com a criação, em 1869, do termo homossexualidade pelo húngaro Benkert ${ }^{32} \mathrm{e}$ posteriormente a criação do conceito de heterossexualidade para descrever a "normalidade", que, segundo Badinter citando Jeffrey Weeks, "postulava uma diferença radical entre os sexos, ao mesmo tempo que ligava de modo indissolúvel a identidade de gênero (ser um homem ou uma mulher) e a identidade sexual." (J. WEEKS, apud BADINTER, 1993, p. 103).

Após a formação do "tipo homossexual" pelos sexólogos, as práticas sexuais passaram a ser o critério de descrição da pessoa, mas as práticas homossexuais já existiam em toda parte e desde sempre, conforme pondera Badinter. No entanto,

até que a sexologia lhe colocasse um rótulo, a homossexualidade era apenas uma parte difusa do sentimento de identidade. A identidade homossexual, tal como a conhecemos, é, portanto, uma produção de classificação social, cujo principal objetivo era a regulação e o controle. Nomear era aprisionar. (J. WEEKS, apud BADINTER, 1993, p. 105).

32De acordo com o professor Luiz Mott, no artigo Em defesa da homossexualidade, Benkert é pseudônimo do jornalista húngaro Karol Maria Kertbeny, que cunhou o termo homossexual em 1869. 
É a partir daí que as questões identitárias passam a ser problematizadas. Afinal, como propõe Badinter, a homossexualidade seria uma pulsão universal ou uma identidade específica de uma minoria? Surgem assim, segundo Badinter, defensores das semelhanças entre homossexuais e heterossexuais, que insistem quanto à universalidade da pulsão homossexual e aqueles que ressaltam as diferenças e as especificidades do homossexual. (BADINTER, 1993, p. 106). Neste espaço turbulento de polêmicas e incertezas nascem não só os movimentos de defesa da homocultura, mas também os estudos da temática. "Escolha ou destino, acidente ou estilo de vida, a homossexualidade é plural e qualquer colocação que vise a unificá-la e reificá-la leva ao impasse. A pulsão é, certamente, universal, mas a preferência sexual não o é." (BADINTER, 1993, p. 113). No final dos anos 1960 surgem os chamados Gay's Studies que, de acordo com Badinter, "tomando consciência de que a homossexualidade é um conceito muito mais amplo do que o de identidade sexual, trataram de mostrar que os homossexuais eram homens como os outros" e que, mesmo que a homossexualidade fosse considerada uma recusa de papéis sexuais tradicionais, a sexualidade não poderia, de forma alguma, determinar o gênero. (BADINTER, 1993, p. 114). É somente a partir disso, segundo Badinter, que os estudiosos da homossexualidade começam a afastar qualquer identificação entre "identidade" e "orientação sexual". (BADINTER, 1993, p. 115).

Mas como distinguir os quatro componentes da sexualidade: orientação sexual, identidade sexual, identidade de gênero e papel social do gênero? Baseando-se nos Princípios de Yogyakarta: princípios sobre a aplicação da legislação internacional de direitos humanos em relação à orientação sexual e identidade de gênero, o Manual de Comunicação LGBT define a orientação sexual como a "capacidade de cada pessoa ter uma profunda atração emocional, afetiva ou sexual por indivíduos de gênero diferente, do mesmo gênero ou de mais de um gênero, assim como ter relações íntimas e sexuais com essas pessoas" 33 . Para o Manual há basicamente três orientações sexuais predominantes: homossexualidade (pelo mesmo sexo); heterossexualidade (pelo sexo oposto) ou bissexualidade (pelos dois sexos). Conforme o Manual, os estudos demonstram que as características da orientação sexual variam de pessoa para pessoa. Outras publicações falam também de assexualidade e pansexualidade. A primeira seria a ausência de atração sexual, daí o fato de muitos estudiosos a caracterizarem como disfunção sexual e não como orientação sexual. A segunda, a capacidade de sentir atração sexual por todos os sexos, gêneros e até mesmo, espécies.

O fato é que inúmeros estudos anteriores à teoria queer atribuíram à identidade homoerótica a conotação de anormalidade. Desta forma, como apontamos até agora, é recorrente, antes dos estudos queer, a ideia da homossexualidade enquanto anormalidade, patologia ou desvio de caráter ou de personalidade. A partir dos estudos gays e lésbicos é que esses estereótipos vão gradativamente perdendo espaço.

33 Manual de Comunicação LGBT, 2010, p. 10. Disponível em: http://www.abglt.org.br/docs/ManvaldeComunicacaoLGBT.pdf. Acesso em: 10 mar. 2011. 
Ainda seguindo a definição dos Princípios de Yogyakarta: princípios sobre a aplicação da legislação internacional de direitos humanos em relação à orientação sexual e identidade de gênero, o Manual de Comunicação LGBT salienta que a identidade de gênero

é uma experiência interna $e$ individual do gênero de cada pessoa, que pode ou não corresponder ao sexo atribuído no nascimento, incluindo o senso pessoal do corpo (que pode envolver, por livre escolha, modificação da aparência ou função corporal por meios médicos, cirúrgicos e outros) e outras expressões de gênero, inclusive vestimenta, modo de falar e maneirismos. Identidade de gênero é a percepção que uma pessoa tem de si como sendo do gênero masculino, feminino ou de alguma combinação dos dois, independente do sexo biológico. Trata-se da convicção íntima de uma pessoa ser do gênero masculino (homem) ou do gênero feminino (mulher). (Manual de Comunicação LGBT, 2010, p. 16). ${ }^{34}$

Seguindo este raciocínio, se a identidade sexual corresponderia ao sexo biológico (masculino ou feminino, atribuído no nascimento), a identidade de gênero, por sua vez, corresponderia ao sentido psicológico de ser masculino ou feminino. Neste sentido, o papel social do gênero seria a extensão do que é considerado na sociedade como comportamento feminino e/ou masculino, conforme defende a American Psychological Association (APS, 2006). Destarte, o papel social de gênero costuma estar associado a particularidades como roupas, acessórios, corte de cabelo, postura etc. Assim, o papel social de gênero pode ser a totalidade de formas na qual uma pessoa pode expressar sua identidade de gênero ou, mais frequentemente, o tipo de atividade que a sociedade determina como apropriada para indivíduos que possuam determinado tipo de genitália externa. Ou seja, se é homem tem que estar e se comportar de tal maneira; se é mulher, de outra maneira.

Note como essas questões relacionadas à identidade, sexo e gênero ou entre desejo, prática e identidade são relativas e vulneráveis. Por exemplo, um homem pode na prática fazer sexo com outro homem, sem que se identifique como homossexual, bissexual ou gay. Ele pode estar tendo a prática homossexual, mas continuar se identificando e sendo heterossexual, conforme ressalva o Manual de Comunicação LGBT $T^{35}$. Ele pode estar numa condição específica como confinado num presídio, num albergue masculino, ou até fazendo o trabalho sexual com clientes do sexo masculino, reforça - Manual e explica que, por essas razões, foram criadas pelos profissionais de saúde siglas (HSH e MSM) ${ }^{36}$ que identificam o comportamento sexual das pessoas e não sua orientação sexual e/ou identidade de gênero, dando

34 Disponível em: http://www.abglt.org.br/docs/ManualdeComunicacaoLGBT.pdf. Acesso em: 10 mar. 2011.

35 Manual de Comunicação LGBT, 2010, p. 18. Disponível em: http://www.abglt.org.br/docs/ManvaldeComunicacaoLGBT.pdf. Acesso em: 10 mar. 2011.

36 Conforme Manual de Comunicação LGBT (2010, p. 18), HSH é a sigla referente a "homens que fazem sexo com homens" e MSM, "mulheres que fazem sexo com mulheres". 
conta da prevenção à AIDS sem adentrar nas questões culturais (identitárias e sexuais).

De acordo com o Manual de Comunicação LGBT, ao se tratar de sexualidade, não existe padrão de normalidade ou anormalidade, pois a manifestação sexual/afetiva é de caráter individual e íntimo dos indivíduos e falar de "normalidade" de uma identidade ou orientação sexual pressupõe que existe um "desvio da norma", uma "anormalidade". ${ }^{37}$ Portanto, posiciona-se o Manual, "normalidade sexual" é uma expressão que deve ser evitada ao referir-se aos segmentos LGBT, pois pode reforçar conceitos relacionados ao preconceito e à discriminação. E mais, afirma o Manual: a orientação sexual não está vinculada ao desempenho sexual com o (a) parceiro(a), pois a sexualidade, independentemente da orientação, envolve um conjunto de fatores emocionais, afetivos, sociais, históricos e biológicos que vão muito além do ato genital. ${ }^{38}$ Assim, a atividade sexual nada tem a ver com a orientação sexual ou identidade de gênero das pessoas. Por exemplo, alguns estudos afirmam que travestis, transexuais e andróginos são considerados identidades de gênero e não "orientações sexuais", uma vez que pode haver travestis, andróginos e transexuais homossexuais, bissexuais, ou até mesmo, assexuais ou heterossexuais. Em outras palavras: se a orientação sexual é a atração afetiva e/ou sexual (o desejo do qual falamos) que uma pessoa sente por outra; o sexo biológico se define como ser macho ou fêmea. A identidade sexual, por seu turno, é a distinção e o entendimento, naturais e subjetivos, de ser homem ou mulher. Consequentemente, o papel social de gênero refere-se a nossa adesão às regras culturais de papéis e comportamento masculino ou feminino.

Além dos cultural studies (estudos culturais) e dos gender's studies (estudos de gênero), mais especificamente dos gays and lesbian studies (estudos gays e lésbicos), muitas outras teorias vão se debruçar sobre as relações entre corpo, gênero, identidade, sujeito e sexualidade, apontar como esses conceitos são instáveis, relativos e movediços, enfim, questionar a tal "normalidade sexual". Entre as mais importantes estão a teoria queer e a estética camp.

\section{Teoria queer e Estética camp}

Ao tocarmos na questão identitária e no travestimento das escrituras homoeróticas torna-se inevitável falarmos da teoria queer e da estética camp. Ambas propõem o questionamento dos ditames da normatividade e têm como marcas a extravagância e a marginalidade, uma vez que dão conta dos transgressores, dos excêntricos, dos "diferentes", isto é, das minorias. Entre as minorias sexuais, as drags queens e outros transgêneros, bem

37 Manual de Comunicação LGBT, 2010, p. 15. Disponível em: http://www.abglt.org.br/docs/ManvaldeComunicacaoLGBT.pdf. Acesso em: 10 mar. 2011.

38 Manual de Comunicação LGBT, 2010, p. 22. Disponível em: http://www.abglt.org.br/docs/ManvaldeComunicacaoLGBT.pdf. Acesso em: 10 mar. 2011. 
como gays e lésbicas são alguns dos objetos de estudo destas correntes teóricas. A teoria queer pretende "romper os espaços fixos e finitos da identidade". (TALBURT, apud FILHO, 2007, p. 18). Por sua vez, a estética camp, conhecida como a estética do exagero ou do grotesco, propõe a investigação das performances de gênero, tomando como base a afetação, a paródia e o deboche destes corpos-identidade. Em suas especificidades, teoria queer e estética camp tentarão descrever o "comportamento fluido e multiforme" da homocultura. O exibicionismo camp e a estranheza queer contestam as noções culturais (fixas e excludentes) de sexo, gênero e identidade.

No dizer de Barcellos, o queer, "empregado no âmbito do que se vem chamando de teoria queer, inscreve-se num amplo movimento de questionamento da identidade gay e de alguns aspectos dos gays and lesbian studies". (BARCELLOS, 2006, p. 28). O queer, segundo Barcellos, foi reapropriado para designar um modelo que se propôs como alternativa a gay, justamente para uma autêntica afirmação da excentricidade, da diferença. Utilizando o próprio termo injurioso em sua denominação, a teoria queer perverte o sentido negativo do termo, desafiando seu sentido pejorativo. O termo queer é uma gíria inglesa que pode ser traduzida como "esquisito", "anormal", "excêntrico", "incomum", "raro", "estranho" ou "diferente" e também é utilizado em tons depreciativos e homofóbicos para designar gays e lésbicas. Podem ser considerados queers: homossexuais, bissexuais, transexuais, travestis, drag queens/kings, entre outros sujeitos de sexualidades desviantes e ambíguas.

$\mathrm{Na}$ contemporaneidade exclui-se a ideia de que possa haver identidades sexuais em transição ou em transformação. Numa perspectiva teórica, queer indica toda e qualquer "identidade" (seja ela sexual ou não) como resultado, sobretudo, de convenções sociais e culturais. Assim nos explica o pesquisador Tomaz Tadeu da Silva:

o termo queer funciona como uma declaração política de que o objetivo da teoria queer é o de complicar a questão da identidade sexual e, indiretamente, também a questão da identidade cultural e social. Através da 'estranheza', quer se perturbar a tranquilidade da 'normalidade'. (SILVA, 2007, p. 42).

Assim, o que se percebe, é que o conceito pós-moderno queer vem questionar os "regimes de normalidade". A teoria queer rompe com a ideia de uma categoria unitária formadora de identidades. De acordo com Judith Butler, aqueles que se confrontam com as normas de gênero e que, ainda assim, buscam um reconhecimento social para ter vidas habitáveis são os sujeitos da teoria queer. (BUTLER, 2003, p. 52). Para a teoria queer, a identidade sexual, assim como a de gênero, é uma construção social. De acordo com tal teoria, a identidade é sempre uma relação dependente da identidade do outro. Não existe identidade sem significação, assim como não existe identidade sem poder. A teoria queer pretende questionar as estruturas de significação sobre o que é correto ou incorreto, o que é moral ou imoral, o que é normal ou anormal. 
Barcellos comenta, concordando com Jeffrey Weeks sobre a necessidade de se distinguir com clareza comportamentos, papéis e identidades no estudo do homoerotismo, pois segundo Weeks, "um comportamento homossexual não gera automaticamente, nem mesmo necessariamente, uma identidade homossexual." (WEEKS, apud BARCELLOS, 2006, p. 30-31). Os sujeitos de identidade homossexual são colocados à margem no sistema cultural que vivemos, pois, sexista, binarista, heterocêntrico, machista, falocrático, androcêntrico e patriarcal, este sistema não abre espaço para as minorias ou para aqueles que se colocam como externos/marginais a este sistema. Toda e qualquer identidade fora deste sistema será considerada ex-cêntrica. Neste sentido, enquanto a teoria queer volta-se para os estranhos, a estética camp foca os excêntricos e ambas estudam os ex-cêntricos.

Muitas travestis, como sabemos, usam e abusam de maquiagens vibrantes, roupas chamativas, acessórios exóticos, cores berrantes, jóias extravagantes, cabelos artificiais, calçados espalhafatosos. Toda essa afetação e artificialidade, bem como esse humor e exagero presentes na montagem e/ou transformação dos corpos travestidos, por vezes caricatos, é objeto de análise da Estética Camp:

A palavra camp é um termo que pode ser traduzido por "fechação" e significa uma aceitação - por parte dos gays - do universo estereotipado criado pela sociedade homofóbica, mas de maneira invertida: buscando valorizar o jargão "homossexual", os gays devolvem à camada bem comportada da sociedade uma transfiguração do grotesco, transformando o estigma do jargão homofóbico em linguagem e ação libertárias. Se concordarmos com Jung, para quem existem os "tipos psicológicos" (ou os "estados psicológicos") "introvertidos e extrovertidos", a estética do grotesco, performatizada pelas drag queens, estaria evidenciando a porção extrovertida do temperamento homoerótico. Nessa direção, as piadas, as caricaturas, o exagero na gestualidade e as linguagens obscenas, utilizados em sua estética espetacularizada, teriam o objetivo de transformar a realidade difícil de ser vivida numa simulação da vida como obra de arte. Por um lado, essa estratégia libera uma dimensão da vivência homoerótica que estivera recalcada historicamente, portanto, consiste numa ação afirmativa que contempla os gays, lésbicas, travestis e transsexuais (sic) como eles são, falam e agem em suas vivências diárias; por outro lado, ratifica os procedimentos de exclusão, porque retrata os gays sempre efeminados, fúteis, promíscuos, espalhafatosos. (PAIVA, 2011 , p. 11).39

Neste sentido, o corpo travesti é plasticidade, performance, espaço de ornamentação e é dessa maneira, pelo excesso, pelo espalhafato que as travestis questionam as normas culturais ou as fronteiras de gênero e chamam a atenção para si, ou na gíria travesti, "causam", abalam estruturas, literalmente! Na estética camp os desmunhecados/afetados (efemi-

39 Disponível em: www.cchla.ufrn.br/bagoas/v01 n01art1 1_paiva.pdf. Acesso em: 6 abr. 2011. 
nados) e travestidos têm vez, pois ela privilegia o exagero, o travestismo, a afetação e a farsa.

A estética camp interessa-se pelas minorias no que elas têm de dual, de ambíguo, de duplo sentido. Segundo Susan Sontag, uma das teorizadoras da Estética Camp, todas as pessoas e objetos possuem um grande componente de artifício e o andrógino, como ser ambíguo, é uma das grandes imagens da sensibilidade Camp. (SONTAG, 1987, p. 322). Deste modo, são híbridos ou ambíguos: travestis, hermafroditas/intersexuais e andróginos, pois carregam em si o signo da dubiedade. Obviamente isso nos interessa de maneira contumaz, uma vez que o travesti está neste terreno fértil da ambiguidade, da (dis)simulação, da dubiedade e do disfarce. A escrita também está plantada neste solo.

\section{Escritura do travestimento}

Se pensarmos em corpos escritos e travestidos é possível estabelecer diversas analogias entre corpo e escrita. São vários os conceitos que encontramos, sobretudo nas áreas pedagógica, filosófica e literária: escrita de escritura, escrita de escrevência, escritura do travestimento, além das definições diversas para escrita, escritura e escrituralidade ${ }^{40}$. Aqui nos ateremos ao conceito de escritura do travestimento cunhado por Severo Sarduy em seu Escrito sobre um corpo (1979).

De acordo com Severo Sarduy, o travesti traz no seu corpo uma aparência de inversão sexual e é "alguém que levou a experiência da inversão a seus limites" (SARDUY, 1979, p. 46). O mundo do travestido é um mundo invertido: "espaço de conversões, de transformações e disfarces: o espaço da linguagem." (SARDUY, 1979, p. 48). Deste modo, a travesti não assume "a imagem de si mesmo", mas a imagem do outro. Sarduy aponta ainda que o travestimento, como uma "adoração implícita do Outro", provoca o disfarce numa tentativa voraz de "vestir-se do Outro". É, pois, segundo ele, a usurpação de uma identidade alheia. O travesti reúne em si a coexistência ou a convergência de significantes masculinos e femininos. Como vimos, a noção de gênero está pautada no dualismo: ou se é um ou se é outro. Entretanto, como vimos com a estética camp e com a teoria queer, isso não se aplica à realidade. No caso dos transgêneros, por exemplo, os binarismos culturais (masculino/feminino; homem/mulher; macho/fêmea) subvertem essa ditadura do gênero. O desejo travesti, por exemplo, é de tornar-se outro, inver-

40 Comentando Schneuwly (1988), Sérgio Roberto Costa explica que escrita, no sentido restrito, seria o domínio de um código, de um sistema ortográfico, enquanto a escritura seria a possibilidade de se representar a linguagem oral por um sistema visual. Em sentido amplo, explica Costa, escrita/escritura seria uma atividade discursiva específica dentro de um sistema de produção global/total discursivo, oral e escrito. (Oralidade, escrita e escritura: diferenças/semelhanças entre as modalidades oral e escrita e o processo de letramento. Disponível em: http:// www.filologia.org.br/ixfelin/trabalhos/pdf/53.pdf. Acesso em: 22 mar. 2011). Para saber mais sobre escrita, escritura e escrituralidade consultar DERRIDA (2002). Sobre o conceito de escrita de escritura consultar BARTHES (2006) e para saber mais sobre o conceito de escrita de escrevência ver BARTHES (2006) e PERRONE-MOISÉS (1983). 
tendo seu gênero, na aparência. No caso dos transexuais, a inversão é ainda maior, pois não fica apenas na aparência. A escrita também propõe uma subversão: a subversão da realidade, o travestimento desta em ficção.

Destarte, a escrita pressupõe montagem, uma vez que é a linguagem se montando para a produção da narrativa; ficção e realidade se montam na composição da narrativa. Os personagens são montados para o desenlace da narração e o autor simula, dissimula e representa. No universo das travestis, esta ideia da montagem já está sendo superada. Entre as travestis não é bem-vinda a ideia de que elas se montam. De acordo com elas, a montagem foi um recurso do passado, conforme se pode perceber na declaração de uma delas ao pesquisador Hugo Denizart:

Falam se montar como travestie Se montar é uma palavra pesada. Parece que pega um pedaço de cada coisa e monta uma coisa qualquer... Seria se transformar, se transformando... Eles usam montagem porque ficou muito aquela coisa de travesti que usa peruca, usava... Há muito tempo atrás, não havia hormônio nem silicone, então, o que eles faziam? Usavam espuma. Aí se montavam e se desmontavam. Montavam um corpo por baixo da roupa e desmontavam. (Indianara). (DENIZART, 1997, p. 34).

Assim, o emprego de 'montagem' se mostra, na visão das travestis, desatualizado. É preciso ressaltar que ainda há casos em que muitas se montam para performances em espetáculos, como no caso de muitos transformistas, drag queens e crossdressers que verdadeiramente se montam para uma performance em espetáculos. Nestes e nos demais casos, as travestis se transformam, algumas vezes irreversivelmente, outras desastrosamente. São muitos os relatos de aplicação mal-sucedida de silicone ou de cirurgias plásticas fracassadas e traumáticas. Mas o que um corpo travestido sugere?

Sarduy utiliza o termo travestimento como metáfora para a escritura, uma vez que ambos, corpo travestido e escritura, são formas de representação e manipulação de signos. O travestimento, assim como a paródia, é uma maneira intertextual de reescritura de textos, podendo ser de sexo, raça, classe ou cultura. O travestimento, portanto, implica disfarce, representação ou simulacro, uma vez que o gesto de travestir está relacionado ao fato de simular ser outro. De acordo com o pensamento derridiano, a escrita provoca sempre uma desconfiança por não passar de uma representação de outra representação. Para Derrida (1997), a escritura é o trabalho da escrita e a palavra escrita é suspeita porque pode ser utilizada mesmo na ausência daquele que a escreveu, contra ele ou a seu favor.

Dando sequência aos nossos raciocínios, ao considerarmos o universo do travestimento, percebe-se uma evidente analogia entre corpo e escritura. Tanto o corpo travestido como a escrita são alvos da prótese, da montagem, da transformação, da transfiguração. É preciso lembrar que assim como o travesti, a escrita também necessita da prótese. No caso específico da literatura essa prótese pode ser entendida como a inovação do léxico e do processo narrativo e o extra-dito, isto é, aquilo que está além do escrito e 
que muitas vezes é denominado interdito por se encontrar subliminar, escondido no universo das entrelinhas, para além do texto. As palavras impressas na página, em sua materialidade, também são consideradas travestimentos do real, afinal elas travestem o que não pode estar ali naquele momento, o referente. A ambiguidade, presente não só na oscilação de gênero do substantivo (o/a travesti) como se costuma presenciar cotidianamente, está também vinculada à escrita, que também pode ser ambígua, duvidosa e suspeita, haja vista que faz uso de artifícios como a metáfora, a ironia, o sarcasmo, o deboche, a crítica, o duplo sentido, o interdito, a representação, a (dis)simulação, entre outros caros recursos linguísticos e discursivos. Assim, é possível conceber a escrita como uma possibilidade de montagem, na medida em que narrativas (vivências e experiências dos sujeitos: travesti e escritor) são sobrepostas a outras narrativas, sobretudo, no discurso metalinguístico, por exemplo, já que a escrita, neste caso, discute o próprio processo de escritura.

O travestido está para o escritor assim como o corpo está para a narrativa. Ambos manipulam signos de superfície. Desta forma, o corpo do indivíduo travestido é manipulado da mesma maneira que as palavras são manipuladas pelo escritor. Em ambos os processos, de escritura e de travestimento, ocorre montagem de uma representação, bem como, em ambos os corpos, da narrativa e do travestido, ocorre simulação de uma realidade ou mascaramento de uma identidade. No corpo travestido mascaram-se as características do sexo oposto para evidenciar as marcas de gênero. No corpo da narrativa mascaram-se as características do real para se evidenciar as marcas da ficcionalidade. Nem sempre estes objetivos são alcançados, mas os vestígios dessa manipulação de signos ficam impressos ou inscritos nos corpos. Escritor e travesti realçam subjetividades, selecionando signos de seu interesse: palavras pelo primeiro, vestimentas e acessórios pelo segundo. Caracteres e características em manipulação, em modelação são inscritos e escritos por seus respectivos autores. Considerando que a paródia e o travestimento são formas intertextuais de reescritura de textos, é possível também falar de uma constante analogia entre intertextualidade (entre textos) e intersexualidade (entre sexualidades). Aqui, intersexualidade não como transgeneridade. Se a primeira pressupõe interação das mais diversas linguagens textuais, a segunda aponta para um diálogo e uma fluidez comum entre os diversos planos de sexualidades, que, como vimos no raciocínio de Judith Butler, não são fixos nem finitos.

A escrita, como nos lembra Sarduy, é uma inscrição e, por analogia, é uma tatuagem. A tatuagem é uma forma de escrita. Ambas se constituem "máscaras", uma vez que mostram e escondem ao mesmo tempo: "a máscara nos faz crer que há uma profundidade, mas o que ela mascara é ela mesma: a máscara simula a dissimulação para dissimular que não é mais que simulação" (BAUDRY, apud SARDUY, 1979, p. 49). A roupa, a vestimenta também cumpre com este papel: revela ou desvela o que pode ser visto, mas vela o que não pode ser visto. Não por acaso, Sarduy compara o autor ao tatuador e a literatura à tatuagem ao comentar a trama de Compact (1966), de Maurice Roche, que traz as figuras de um colecionador de peles e seu assistente travesti: 
A literatura é, como a que pratica nosso colecionador, uma arte da tatuagem: inscreve, cifra na massa amorfa da linguagem informativa os verdadeiros signos da significação. Mas essa inscrição não é possível sem ferida, sem perda. Para que a massa informativa se converta em texto, para que a palavra comunique, o escritor tem que tatuá-la, que inserir nela seus pictogramas. A escritura seria a arte desses grafos, do pictural assumido pelo discurso, mas também a arte da proliferação. A plasticidade do signo escrito e seu caráter barroco estão presentes em toda literatura que não esqueça sua natureza de inscrição, o que se poderia chamar escrituralidade. (SARDUY, 1979, p. 53-54; grifos do autor).

As figuras do colecionador de peles e da travesti estão vinculadas ao travestimento do travestimento, isto é, simulacros do real. A pele da escrita é a pele do corpo que, por sua vez, faz alusão à escrita mascarada, "a 'escritura como travestimento', como desdobramento paródico e translação metafórica". (CAMPOS, in SARDUY, 1979, p. 8). Por sua vez, a escrita nasce pelo desejo do desvelamento e se estende por sua inabilidade em desvelar. Os movimentos do velar/desvelar despertam mecanismos de "aparecimentodesaparecimento", de zonas de intermitência que configuram o texto como corpo erótico, tal qual nos aponta Roland Barthes em O prazer do texto:

O lugar mais erótico de um corpo não é lá onde o vestuário se entreabre? Na perversão (que é o regime do prazer textual) não há "zonas erógenas" (expressão aliás bastante importuna); é a intermitência, como o disse muito bem a psicanálise, que é erótica: a da pele que cintila entre duas peças (as calças e a malha), entre duas bordas (a camisa entreaberta, a luva e a manga); é essa cintilação mesma que seduz, ou ainda: a encenação de um aparecimento-desaparecimento. (BARTHES, 1996, p. 16).

Mas se a escrita é capaz de dissimular tanto, de brincar de mostrar e esconder, de travestir-se de representação, de mascarar-se, de se metamorfosear a ponto de criar uma para-realidade, não faria o criador uma espécie de extensão de sua realidade? Não poderia o escritor prolongar-se para dentro de sua própria obra? A arte não poderia imitar a vida? A escrita não poderia ser vivificada e a vida escrita? Por que não?!

\section{Considerações Finais}

Sendo o travestimento uma tensão entre os significantes masculino e feminino, portanto naturalmente repleta de ambiguidades, é ele que torna a escritura um espaço para o disfarce e a transformação. Dessa forma, a travesti é marcada, assim como a narrativa, o corpo escrito, por uma dubiedade. No caso da travesti deixa-se evidenciar a dubiedade de gênero; no caso da narrativa, a dubiedade da própria linguagem, do discurso que 
utiliza vários recursos, já citados, para sustentar a enunciação. Neste mister, muitas vezes ocorre um desejo de autorrepresentação. Como já apontamos entra em cena o desejo de se travestir a própria vida em escrita ou o desejo do escritor de se produzir no texto, como prefere Schneider (2003) em Ladrões de palavras.

É bem verdade que Michel Foucault e Roland Barthes propuseram, em 1969, a morte do autor[i], mas é inegável que a escrita pode ser contaminada pelas vivências do escritor, afinal se é possível que a obra esteja impregnada na vida de seu autor, por que não o contrário?! A narrativa pode se erguer da memória do autor, que contaminado pelo real, escreve sua ficção ou impregnado de inventividade, produz suas memórias de vida. Como recordar (re = de novo, repetir/cordis = coração) é trazer de volta ao coração, escrever é reviver experiências ou, no senso comum, recordar é viver. Viver e escrever são, pois, processos análogos. De acordo com o conceito de 'vida escrita' proposto por Ruth Silviano Brandão, escrever e viver seriam processos relacionados e contínuos:

O que chamo de vida escrita é a unidade entre escrever e viver e vice-versa, pois a escrita se faz por seus traços de memória marcados, rasurados ou recriados, no tremor ou firmeza das mãos, no pulsar do sangue que faz bater o coração na ponta dos dedos, na superfície das páginas, da tela, da pedra, e onde se possam fazer traços, mesmo naquilo que resta desses traços, naquilo que não se lê, o que se torna letra, som ou sulco, marcas dessa escavação penosa que fazemos no real. (BRANDÃO, 2006, p. 28).

A crítica ressalva que é necessário ter cautela ao articularmos vida e obra, mas isso não quer dizer que essa articulação não seja possível, afinal, escrever seria vital, pois a escrita seria o desejo ou a necessidade de tornar a vida possível. Viver e escrever seriam, pois, formas de se inscrever no mundo e escrever sua própria existência. Deste modo, segundo este conceito, o autor é filho de sua obra e a vida escrita é a vida que se escreve. Assim, o autor emergiria de sua própria obra.

Personagens travestis são recorrentes em diversos filmes, seriados, telenovelas, músicas, peças teatrais, minisséries; e na literatura não é diferente, sobretudo na literatura contemporânea. Escritores como Lúcio Cardoso, Cassandra Rios, Elvira Vigna, Roberto Drummond, Mehmet Murrat Samer, Rubem Fonseca, Severo Sarduy, António Lobo Antunes, José Donoso, Caio Fernando Abreu, Silviano Santiago, Paulo Lins, Drauzio Varella, entre outros, abusaram desta imagem, tanto denotativa quanto metaforicamente.

As narrativas literárias que apontam para as questões de gênero expõem "realidades" alternativas, além de problematizarem e questionarem as construções sociais. O gênero, tal como a tecnologia, é fruto das relações sociais e questiona, através dos mais diversos recursos tecnológicos, a normatividade imposta. Contemporaneamente, a literatura tem sido vista e distribuída nas/das mais diversas formas de tecnologia da comunicação: 
internet, TV, vídeo, áudio, reprodução musical etc. Entendemos que a literatura, o cinema, a teledramaturgia, o teatro e a pintura, são manifestações tecnológicas, uma vez que também são formas de arte, técnica e conhecimento. Destarte, gênero e tecnologia estão naturalmente imbricados, na medida em que permitem questionar a cultura e a sociedade e afirmar que a humanidade vive, desde sempre, em constante devir, performatividade e/ ou relativização.

\section{Referências}

ASSOCIAÇÃO Brasileira de Lésbicas, Gays, Bissexuais, Travestis e Transexuais. Manual de Comunicação LGBT. São Paulo: ABGLT, 2010. Disponível em: http://www.abglt.org.br/docs/ManualdeComunicacaoLGBT.pdf. Acesso em: 10 mar. 2011.

BADINTER, Elisabeth. XY: sobre a identidade masculina. Trad. Maria Ignez Duque Estrada. 2. ed. Rio de Janeiro: Nova Fronteira, 1993.

BARCELLOS, José Carlos. Literatura e homoerotismo em questão. São Paulo: Dialogarts, 2006.

BARTHES, Roland. O prazer do texto. Trad. J. Guinsburg. São Paulo: Perspectiva, 1996.

BENEDETTI, Marcos Renato. Toda feita: o corpo e o gênero das travestis. Rio de Janeiro: Garamond, 2005.

BRANDÃO, Ruth Silviano. A vida escrita. Rio de Janeiro: 7Letras, 2006.

BUTLER, Judith. Problemas de gênero: feminismo e subversão da identidade. Rio de Janeiro: Civilização Brasileira; 1990, 2003.

CAMPOS, Haroldo de. No limiar do Opus Sarduy. In: Severo Sarduy. Escrito sobre um corpo. Trad. Lígia Chiappini Moraes Leite e Lúcia Teixeira Wisnik. São Paulo: Perspectiva, 1979. p. 7-9.

COSTA, Jurandir Freire. A inocência e o vício: estudos sobre o homoerotismo. 3. ed. Rio de Janeiro: Relume-Dumará, 1992.

DENIZART, Hugo. Engenharia erótica: travestis no Rio de Janeiro. Rio de Janeiro: Jorge Zahar Editor, 1997.

DERRIDA, Jacques. A farmácia de Platão. Trad. Rogério Costa. São Paulo: Editora lluminuras, 1997.

FILHO, Adair Marques. Arte e Cotidiano: experiência homossexual, teoria queer e educação. Goiânia: Faculdade de Artes Visuais da UFG, 2007, 125p. (Dissertação de Mestrado em Cultura Visual).

GAGNON, John H. Uma interpretação do desejo: ensaios sobre o estudo da sexualidade. Trad. Lucia Ribeiro da Silva. Rio de Janeiro: Garamond, 2006. 
HOUAISS, Antônio. Minidicionário Houaiss da língua portuguesa. 2. ed. Rio de Janeiro: Objetiva, 2004.

KULICK, Don. Travesti: prostituição, sexo, gênero e cultura no Brasil. Trad. Cesar Gordon. Rio de Janeiro: Editora Fiocruz, 2008.

LACAN, Jacques. Escritos. São Paulo: Perspectiva, 1978.

MORETO, Bruno Penteado Natividade. Desejo e escritura num Flaubert de juventude. São Paulo: Faculdade de Filosofia, Letras e Ciências Humanas da USP, 2008. 129p. (Dissertação de Mestrado em Teoria da Literatura).

PAIVA, Cláudio Cardoso de. Imagens do homoerotismo masculino no cinema: um estudo de gênero, comunicação e sociedade. Disponível em: <www. cchla.ufrn.br/bagoas/v01n01art11_paiva.pdf> Acesso em: 6 abr. 2011.

SARDUY, Severo. Escrito sobre um corpo. Trad. Lígia Chiappini Moraes Leite e Lúcia Teixeira Wisnik. São Paulo: Perspectiva, 1979.

SILVA, Hélio R. S. Travesti: a invenção do feminino. Rio de Janeiro: RelumeDumará, 1993.

SILVA, Tomaz Tadeu da. Documentos de identidade: uma introdução às teorias do currículo. Belo Horizonte: Autêntica, 2007.

SONTAG, Susan. Contra a interpretação. São Paulo: L\&PM Editores, 1987. 